U.S. Department of Energy

Assistant Secretary for Intergovernmental and Institutional Relations

Division of Labor Affairs

and Manpower Assessment

\title{
Radiation Protection Enrollments and Degrees, 1978.
} Enrollments 伤all 1978

Degrees Granted-

July 1966-June 1978

August 1979 


\section{DISCLAIMER}

This report was prepared as an account of work sponsored by an agency of the United States Government. Neither the United States Government nor any agency Thereof, nor any of their employees, makes any warranty, express or implied, or assumes any legal liability or responsibility for the accuracy, completeness, or usefulness of any information, apparatus, product, or process disclosed, or represents that its use would not infringe privately owned rights. Reference herein to any specific commercial product, process, or service by trade name, trademark, manufacturer, or otherwise does not necessarily constitute or imply its endorsement, recommendation, or favoring by the United States Government or any agency thereof. The views and opinions of authors expressed herein do not necessarily state or reflect those of the United States Government or any agency thereof. 


\section{DISCLAIMER}

Portions of this document may be illegible in electronic image products. Images are produced from the best available original document. 
Available from:

National Technical Information Service (NTIS)

U.S. Department of Commerce

5285 Port Royal Road

Springfield, Virginia 22161

Price: Printed copy: $\$ 5,25$

Microfiche: $\$ 3.00$

For sale by the Superintendent of Documents, U.S. Govermmeit Printing Oflice Washington, D.C. 20402

Stock Number 061-000-00335-3 
and Institutional Relations

Division of Labor Affairs

and Manpower Assessment

Washington, D.C. 20585

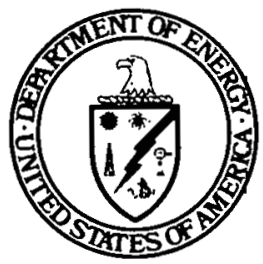

\section{Radiation Protection Enrollments and Degrees, 1978} Enrollments/Fall 1978

Degrees GrantedJuly 1966-June 1978

August 1979

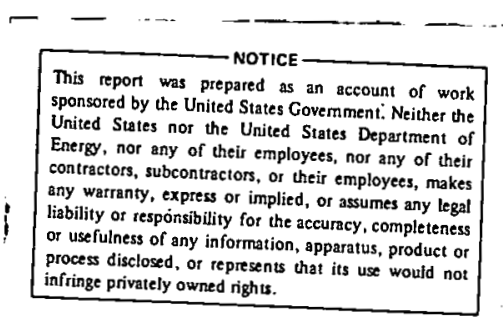


The demand for radiation protection personnel has continued to increase. Radiation Protection Enrollments and Degrees gives the results of the latest survey of institutions offering degree programs in this field. Students obtaining such degrees are vital to the continued development and use of radioactive materials in industry, medicine, research, power production, construction, and agriculture.

This publication would not be possible without the sincere interest and cooperation of those individuals and universities who supplied the information. We thank them on behalf of all who use this document. 
TABLE OF CONTENTS

Page

INTRODUCTION. . . . . . . . . . . . . . . . . . 1

HIGHLIGHTS. . . . . . . . . . . . . . . . . . 3

ENROLLMENTS AND DEGREES . . . . . . . . . . . . . . . 6

Doctorates ..................... . . . 6

Masters. . . . . . . . . . . . . . . . . . 6

Bachelors. . . . . . . . . . . . . . . . 8

PLACEMENT OF GRADUATES. . . . . . . . . . . . . . . . . 10

WOMEN AND MINORITIES: . . . . . . . . . . . . . . . 13

FOREIGN NATIONALS . . . . . . . . . . . . . . . . . . 13

REGIONAL DISTRIBUTION . . . . . . . . . . . . . . 14

CHARTS :

1. Degrees Granted in Radiation Protection, 1966-1978 . . . . 2

2. Placement Trends by Degree Level in Radiation Protection 11

Based on percent of known placement 1973-1978. . . . . .

TEXT TABLES:

1. Total Enrollment of Full-Time and Part-Time Students in

Radiation Protection by Educational Level Falt 1973

Through Fall 1978................. 5

2. Full-Time and Part-Time Graduate Enrollment Fall 1978

and Degrees Granted 1977-78 in Radiation Protection by

Subfield . . . . . . . . . . . . . . . .

3. Full-Time and Part-Time Undergraduate Enrollment Fall 1978 and Bachelor's Degrees Granted 1977-78 in Radiation

Protection by Subfield

4. Placement of 1977-78 Radiation Protection Graduates

by Degree Levels . . . . . . . . . . . . . . . . . 12

5. Participation by Foreign Nationals, Women, and Minorities in

Radiation Protection Programs, 1973-1978 . . . . . . . . . 


\section{APPENDICES:}

Appendix A. Statistical Tables................ 16

A-1. Degrees Granted 1968-1978 by Institution . . . . . . 17

A-2. Enrollments and Degrees in Subfields by Institution. . . . 22 .

A-3.. Minorities, Women and Foreign Nationals Enrollments and Degrees by Institution .................. 31

A-4. Radiation Protection Curriculum or Options by Undergraduate or Graduate Institution. ...... 40

A-5. Number of Enrollments and Degrees by State and Region. . . 45 Appendix B. Addresses . . . . . . . . . . . . . 4 48

$\ddot{B}-1$. Addresses of Institutions in Survey Universe with Active Programs. . . ............ . 48

B-2. Addresses of Institutions in Survey Universe with Inactive or Discontinued Programs. . ........ 51 Appendix c. Survey Materials. . . . . . . . . . 52 


\section{INTRODUCTION}

This report presents the results of the eighth annual survey of Radiation Protection Enroliments and Degrees. "Each year the survey is sent to institutions offering degrees in radiation protection and in other closely related fields (health physics, radiation heaith, radiological physics, radiobiology and similar programs) whose graduates would be prepared to conduct; coordinate, direct, or plan a program for the evaluation and control of radiation hazards in various settings: The number of institutions that are surveyed may change from year to year as new programs are identified and other programs are discontinued. For this year's survey, one institution (Carnegie-Mellon University) reported that its program had been discontinued, and five institutions reported continuing programs but no students.

For the first time in this survey report, the addresses of institutions in the survey universe are separated into two groups. Appendix B-1 includes the addresses of schools with active programs. Appendix $\mathrm{B}-2$ includes addresses of schools with inactive and discontinued programs. 


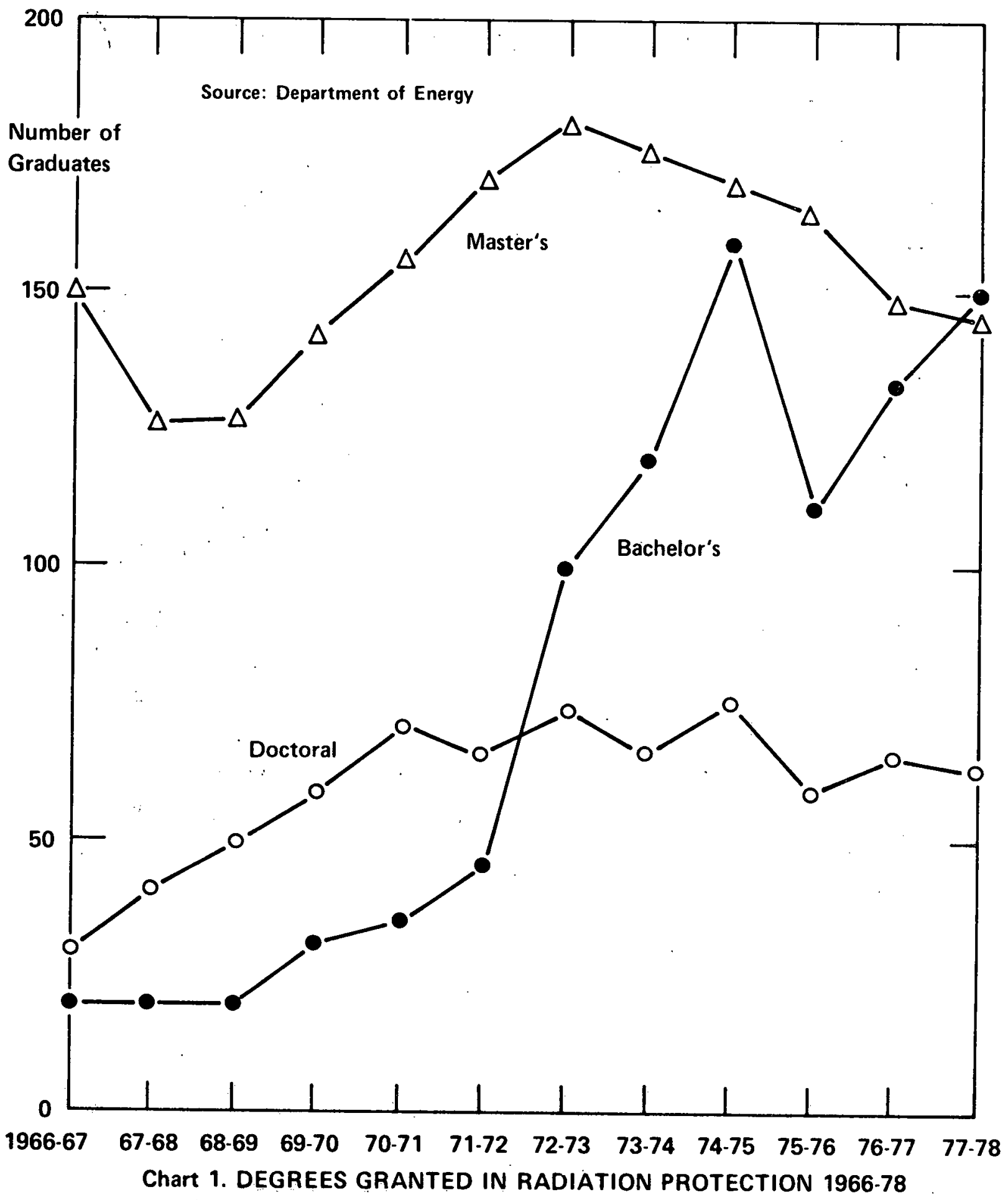




\section{HIGHLIGHTS}

SURVEY UNIVERSE

The 1978 survey included 56 institutions that reported degrees and enrollments. One school had discontinued its program since the previous survey; five others had continuing programs, but reported no students.

\section{ENROLLMENT}

Enrollment decreased by 19 percent at the undergraduate level and rose by 5 percent at the master's level. At the doctoral level, there were 15 more candidates (a five percent increase).

\section{DEGREES AWARDED}

The number of degrees awarded at the three levels presented a varied picture when compared to the prior year: bachelor's degrees increased by 13 percent, master's degrees fell by less than one percent, and doctoral degrees decreased by five percent.

\section{PLACEMENT}

The number of bachelor's and master's degree recipients who went on for further study dropped 15 percent and 2 percent, respectively, from the prior year. Even so, further study is the largest placement category for master's degree recipients. At the doctoral level 24 percent obtained employment in academia. Placements in medical facilities and industry were the largest categories, each totaling 65 degree recipients at all levels. The large number of unknown placements reported at all degree levels presented a difficult problem in portraying any major placement trends. 
MINORITIES AND WOMEN:

The number of Blacks decreased at the undergraduate level, and representation of other minority groups remained low. Undergraduate females decreased significantly. However, women students received a larger proportion of undergraduate and graduate degrees in 1978 than in 1977.

\section{FOREIGN NATIONALS:}

Foreign national enrollments increased in all but the senior level. The number of bachelor's degrees earned by foreign nationals increased, but the number of graduate degrees, decreased.

REGIONAL DISTRIBUTION:

Undergraduate enrollment was highest in the Middle Atlantic region, which had 29 percent of the total enrolled. However, the Pacific region contained the largest proportion of graduate students (24 percent of the total). By state, New York awarded the largest number of bachelor's degrees, Georgia had the largest number of master's degrees, and California granted the largest number of doctorates. 
TABLE 1

TOTAL ENROLLMENT OF FULL-TIME AND PART-TIME STUDENTS

IN RADIATION PROTECTION, BY EDUCATIONAL LEVEL

FALL 1973 THROUGH FALL 1978

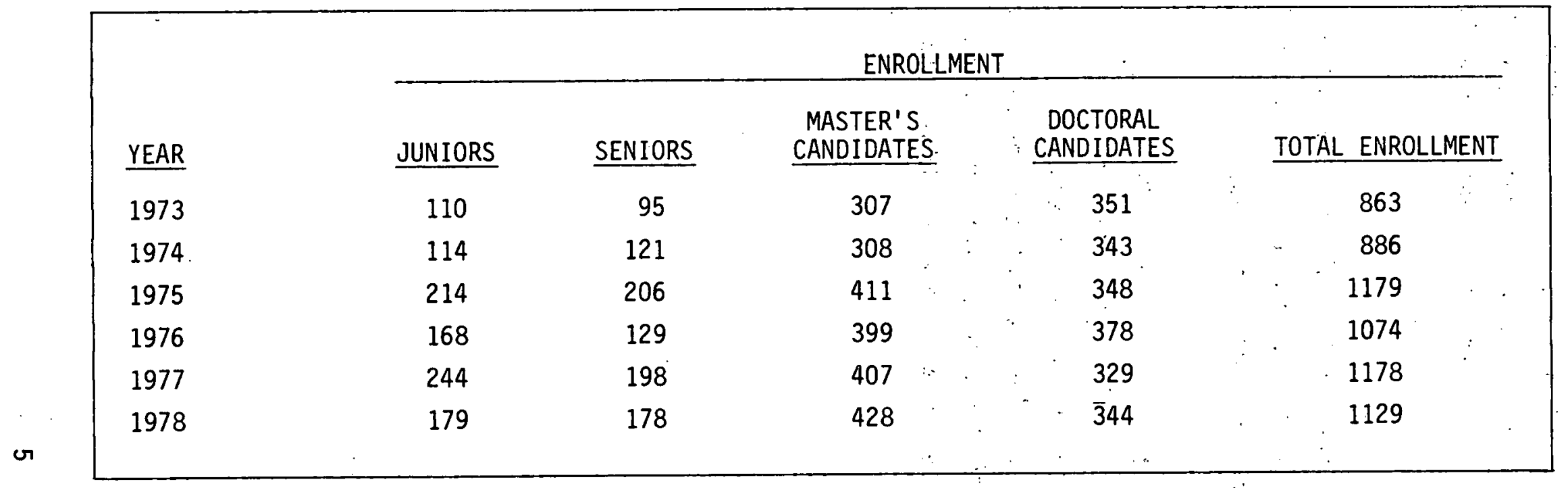

SOURCE: Department of Energy 


\section{ENROLLMENTS ÁND DEGREES}

\section{DOCTORATES}

In Fall 1978, 302 full-time and 42 part-time doctoral candidates were enrolled. These numbers represent a five percent increase in full-time and a two percent increase in part-time students. However, the number of doctorate degrees granted was five percent lower than the previous year (from 67 in 1977 to 63 in 1978), and considerably below the peak years of 1972-73 and 1974-75, which registered 76 and 77 doctorates granted, respectively (see Chart 1 and Appendix A-1).

As presented in Table 2, the largest two subfields in enrollments were radiobiology or biophysics (40 percent of total) and medical radiation physics or radiotogical physics (26 percent of total). The two largest specialization subfields, for those who recently received doctorates were health physics, radiation health or radiation protection (33 percent of total) and radiobiology or biophysics (30 percent of total).

MASTERS

There were a total of 428 master's degree candidates (315 fulltime and 113 part-time) enrolled in the fall of 1978. Both full-time and part-time enrollment increased for a total enrollment increase of five percent over the fall of 1977 (see Table 2).

During academic year 1977-78, there were 146 master's degrees granted. For the fifth straight year, the number of 'master's degrees granted has declined from the record 181 degrees awarded in 1972-73 (see Chart 1). Of al1 reporting institutions, 34 (or 67 percent) awarded master's degrees. However, five schools accounted for onethird of the total number of master's degrees awarded.

The largest number of degrees, 61 (or 42 percent), were granted in the health physics, radiation protection or radiation health subfield (see Table 2). The next biggest group of master's degrees granted, 31 (or 21 percent of total) were in subfields 1 isted separately by respondents. 
TABLE 2

FULL-TIME AND PART-TIME GRADUATE ENROLLMENT (FALL 1978) AND DEGREES GRANTED (1977-78) IN RADIATION PROTECTION BY SUBFIELD

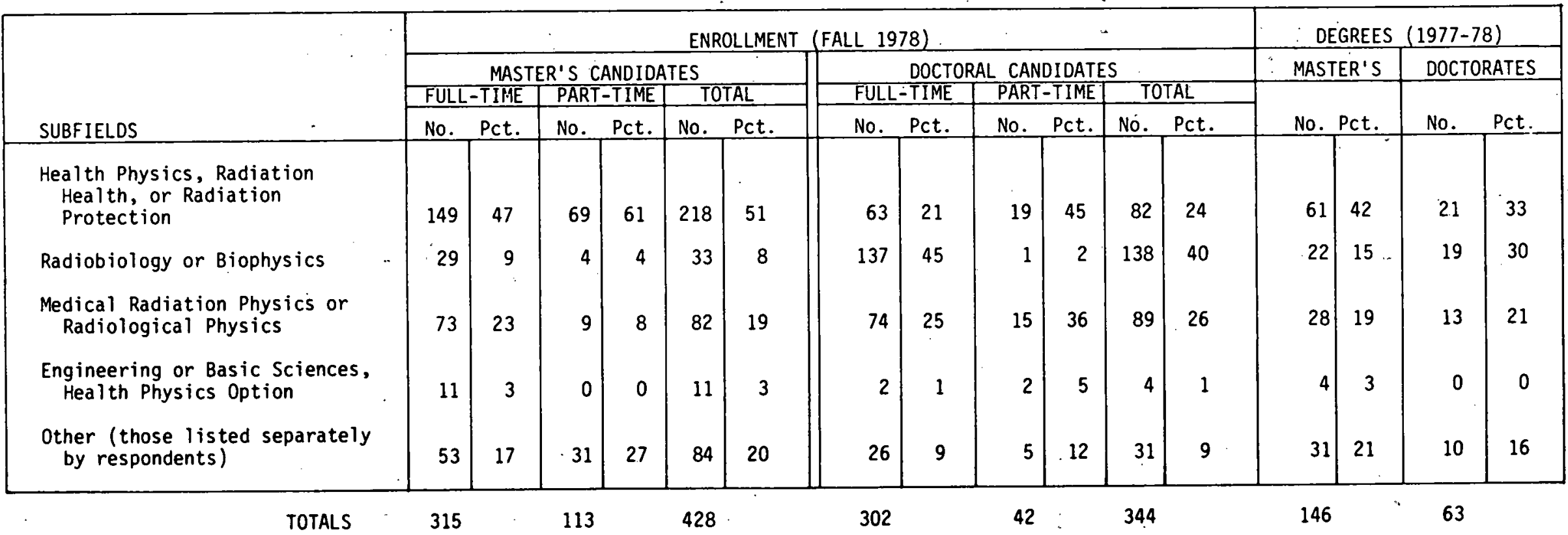

NOTE: Percentages may not add to 100 because of rounding.

Source: Department of Energy. 


\section{BACHELORS}

A decrease was reported in undergraduate enroliment at both the junior and senior levels. The 126 full-time and 53 part-time juniors who registered represent a 27 percent decrease compared with the previous year. At the senior level, 178 (131 full-time and 47 parttime) students were reported, a 10 percent decrease (see Table 3).

There were 151 bachelor's degrees granted during 1977-78, a 14 percent increase over 1976-77, and the second Targest number recorded since the initial survey; 1974-75 remains the peak year with 159 bachelor's degrees.

When comparing the undergraduate enrollment within the radiation protection area, the leading subfield category is health physics, radiation health or radiation protection. Closely following are the institutionally specific subfields listed separately by respondents. This same situation is evident when the subfields for bachelor's degrees are examined. Seventy-six out of 151:(or 50 percent) bachelor's degrees were awarded in health physics, radiation health, or radiation protection. Fifty-one (or 34 percent) of the bachelor's degrees were awarded in subfields listed separately by respondents. 
TABLE $\dddot{3}$

FULL-TIME AND PART-TIME UNDERGRADUATE ENROLLMENT (FALL 1978) AND BACHELOR'S DEGREES: GRANTED (1977-78)

IN RADIATION PROTECTION - BY SUBFIELD

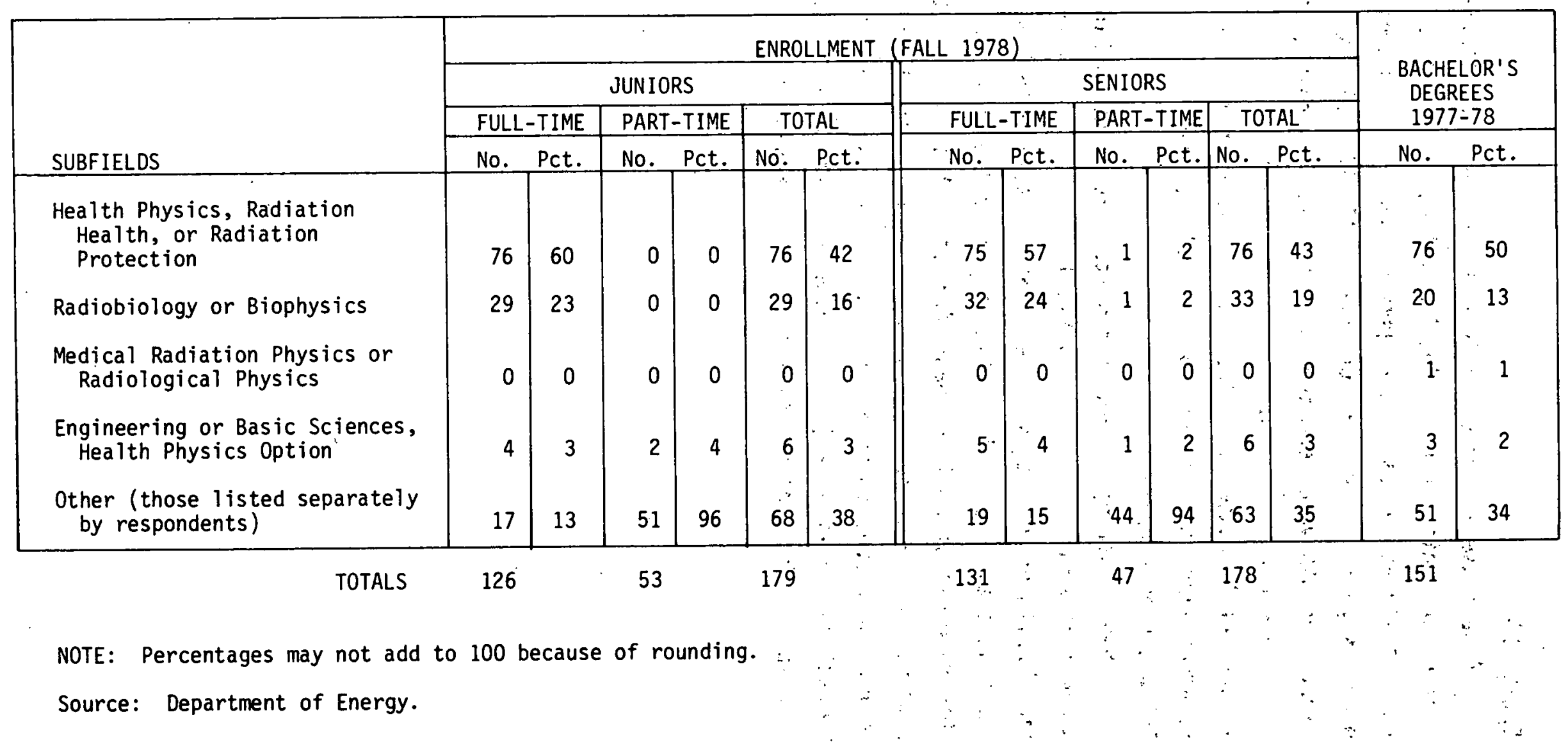




\section{PLACEMENT OF GRADUATES}

New doctorate holders most often found employment in two categories: academic institutions or medical facilities. The former absorbed 24 percent of these graduates, whereas the latter provided jobs for 16 percent. Government-Owned Contractor-Operated facilities took only five new doctorates compared to 13 in 1976-77, a decitine of 12 percent. Most other known placement categories fluctuated a few percentage points. As in the previous survey, no recent doctoral graduates were reported as still seeking employment, a sign of a strong occupational demand for doctorates in radiation protection. However, the substantial absence of data from one school has made it difficult to portray any major placement trends.

As shown in Table 4, the largest group of master's graduates elected to continue their studies (22 percent of the tota1). Two other categories which took sizable proportions of master's degree recipients were medical facilities (16 percent) and private industry (15 percent). As depicted in Chart 2, placement in the military was the highest in five years: ( 5 percent). The fact that one master's recipient was reported as still seeking employment, would also indicate a strong market demand.

P. lacement of new bachelor's degree holders was divided mainly into U.S. industry (26 percent) and into medical facitities (21 percent). The third largest group (11 percent) chose further study. However, this group decreased considerably from 35 recipients in 1976-77 to 16 recipients. Only three recent bachelor's degree holders were reported to be still seeking employment. As with the doctoral recipients, the lack of placement data has made it difficult to portray any major placement trends. 
Chart 2. MANOR PLACEMENT TRENDS BY DEGREE LEVEL IN RADIATION PROTECTION

Based on percent of known placement 1973-78
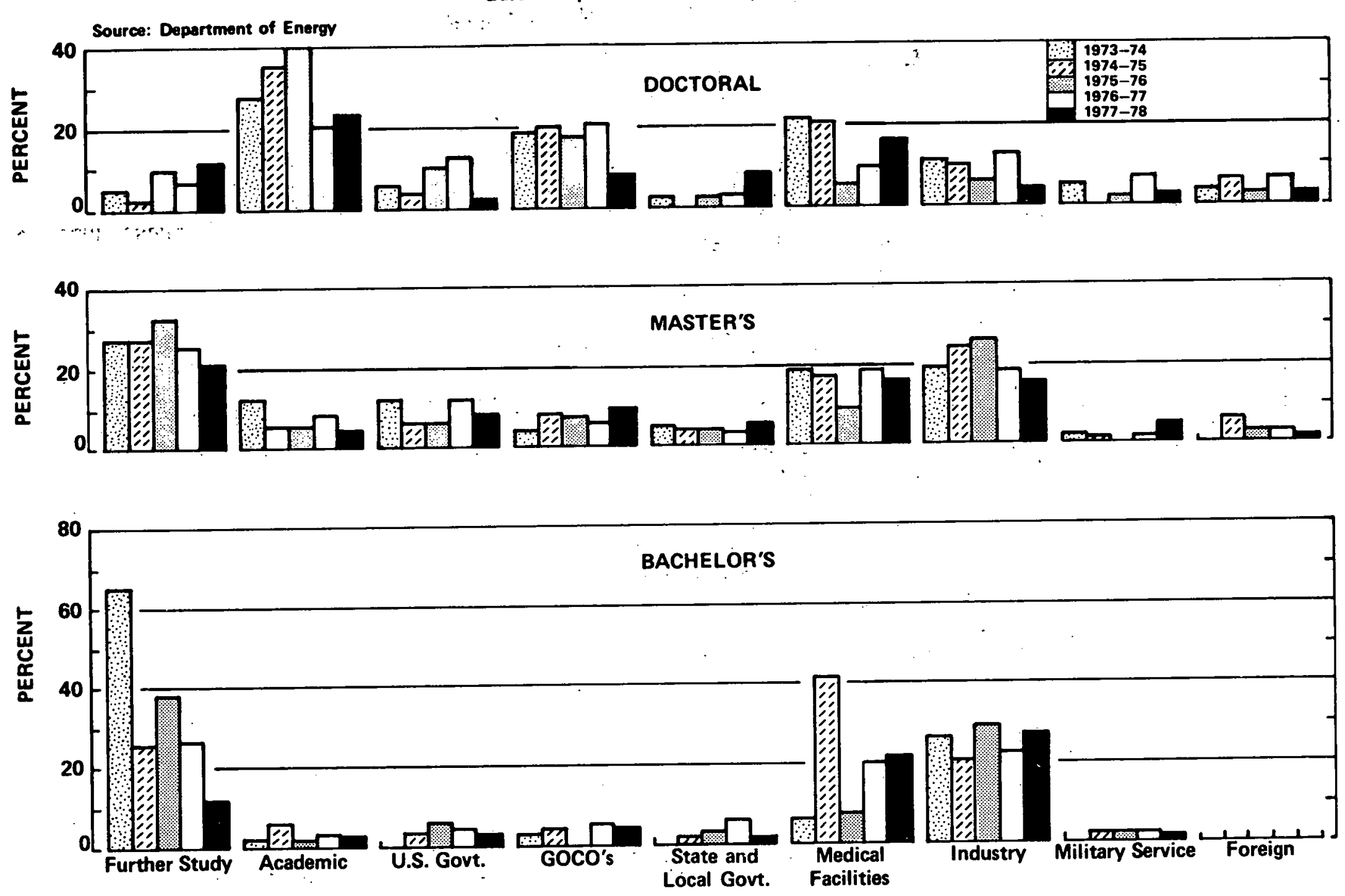

EMPLOYERS 
TABLE 4

PLACEMENT OF 1977-78

RADIATION PROTECTION GRADUATES

BY DEGREE LEVELS

Further study.

BACHELORS

MASTERS:

DOCTORATES

Academic U.S.

5

33

7 . .

Federäl employment

4

6

15

GOCO (Government-Owned

Contractor-Operated).

State and local government

2

1.1

2

6

13

5

Medical facilities

31

7

5

Industry, U.S.

40

24

10

Foreign

0

22

3

Military

2

$\therefore 2$

2

1

other

1

8

0

Seeking employment

3

3

Unknown

TOTALS

41

151

16

13

146

63

Source: Department of Energy 
At the undergraduate level, enrolimen't of women decreased significantly. The number of female juniors decreased from 70 in 1976-77 to 17 in 1977-78 (from 29 to 16 percent of the total, respectively); the number of women seniors fell from 45 to 35 , or from 23 percent to 27 percent. Enrol Iment of women at the master's level remained relatively stable. The survey results indicated a decline in the number of female doctoral candidates (from 36 to 22). Doctoral degrees awarded to women increased from four to five: As shown in Table 5, the highest number of women since this survey was initiated received bachelor's degrees (up from 17 percent of total in 1976-77. to a current 25 percent). About the same number of women received master's degrees and doctorates both years.

Enrollment of Blacks is down in both undergraduate classes to a current 11 percent of total. The proportion of Blacks receiving bachelor's degrees climbed from seven percent of total (in 1976-77) to 13 percent (in 1977-78). There was also an increase in the number of master's degrees and doctorates awarded to Blacks.

Enrollment of Spanish. Surnamed students decreased at the undergraduate junior level, but increased at the senior level. At all other levels, the enroliment remained extremely low. The number of Asian Americans fell in enroliment at the undergraduate level, but increased at the graduate level. There was one master's and one doctorate candidate and no degrees granted to Asian Americans.:

FOREIGN NATIONALS

Although the enrollment of foreign nationals increased at the undergraduate level, it is still very small (nine juniors and one senior). The number of master's students rose from 28 to 37. Doctoral enrollment rose only marginally from 39 students to 43.

Foreign nationals were awarded four bachelor's degrees (four percent), 12 master's degrees (11 percent), and seven doctorates (16 percent) during 1977-78. As illustrated in Table 5, although the percentage of foreign nationals receiving bachelor's degrees has been negligible, the proportion of graduate degrees (both masters and doctorates) has risen to approximately 13 percent of the graduate degrees awarded in radiation protection. 


\section{REGIONAL DISTRIBUTION}

The Middle Atlantic region, with 105 juniors and seniors (or 29 percent of total), contained the largest proportion of enrolled undergraduates (see Appendix A-5). New York alone accounted for 27 percent of the undergraduates enrolled in radiation protection. However, most of the undergraduates enrollment in New York was part-time and located at one institution, Manhattan College. If only full-time undergraduates were compared, Virginia contained the largest proportion. Four states (New York with 35, California with 23, Virginia with 19, and Indiana with 17) produced 51 percent of the total bachelor's degrees awarded in 1977-78.

In contrast, the two largest regions for graduate student enrollment were the Pacific region (with 185 students, or 24 percent of total) and the East North-Central region (with 148 students, or 19 percent of tota1). California, with 19 percent of the total, was the state with the largest number of graduate students enrolled. The three states that produced the most master's degrees were Georgia (18), Colorado (15), and Indiana (15). At the doctorate level, California was the leading state, with 14 degrees granted, and New York was second, with seven degrees awarded. 
TABLE 5

PARTICIPATION BY FOREIGN NATIONALS, WOMEN, AND MINORITIES IN RADIATION PROTECTION PROGRAMS

$$
\text { 1973-1978 }
$$

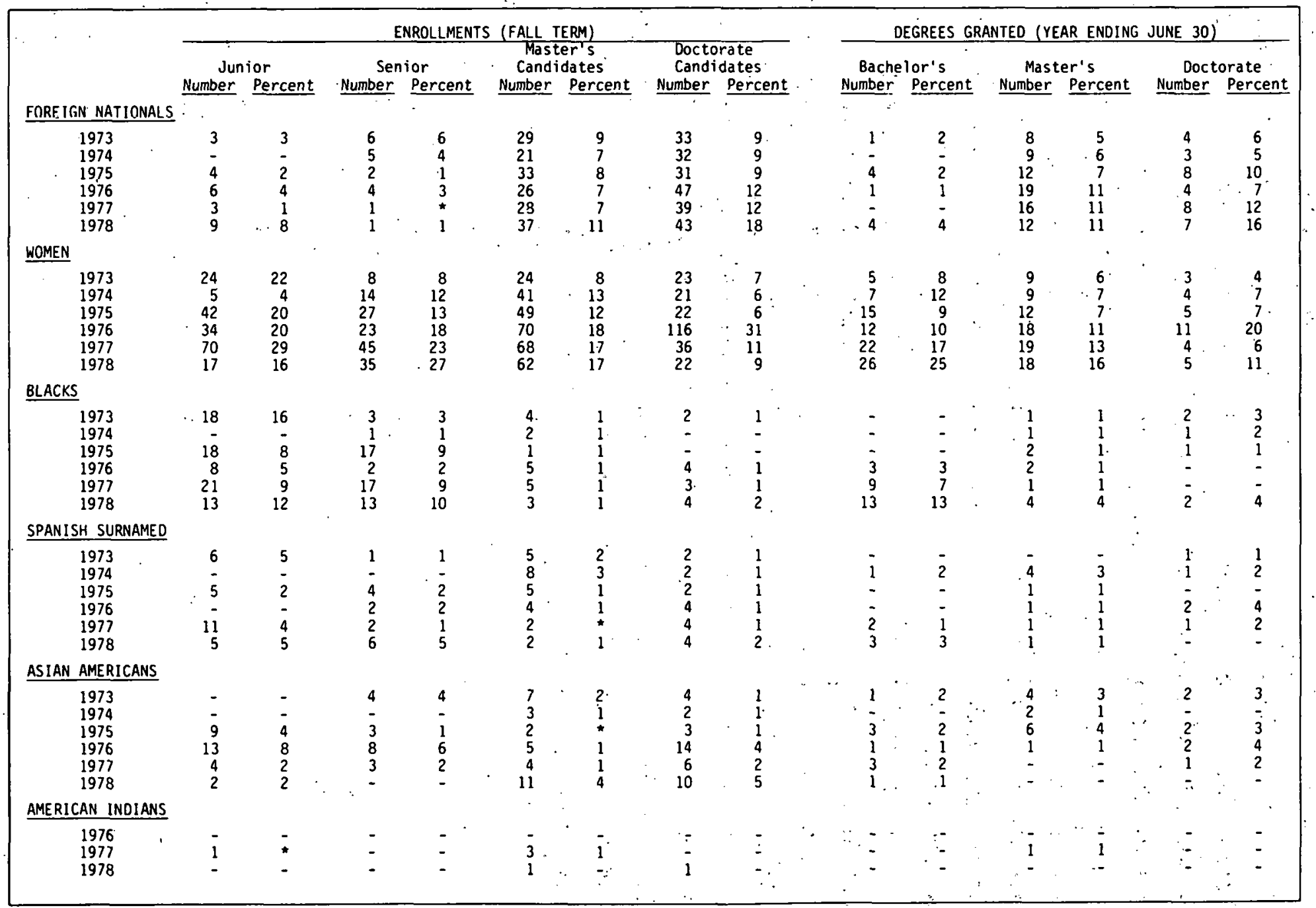

-Less than y of 1 percent.

NOTE: Percentages of enrollment and degrees granted are based on total enrollment and degrees granted by all institutions reporting in that respective year.

Source: Department of Energy 
APPENDICES

Appendix A. Statistical Tables

Appendix B. Addresses

Appendix C. Survey Materials 
APPENDIX A-1

RADIATION PROTECTION

DEGREES GRANTED 1968-1978

$8 y$ Institution

$B=$ Bachelors

$M=$ Masters

$D=$ Doctorate

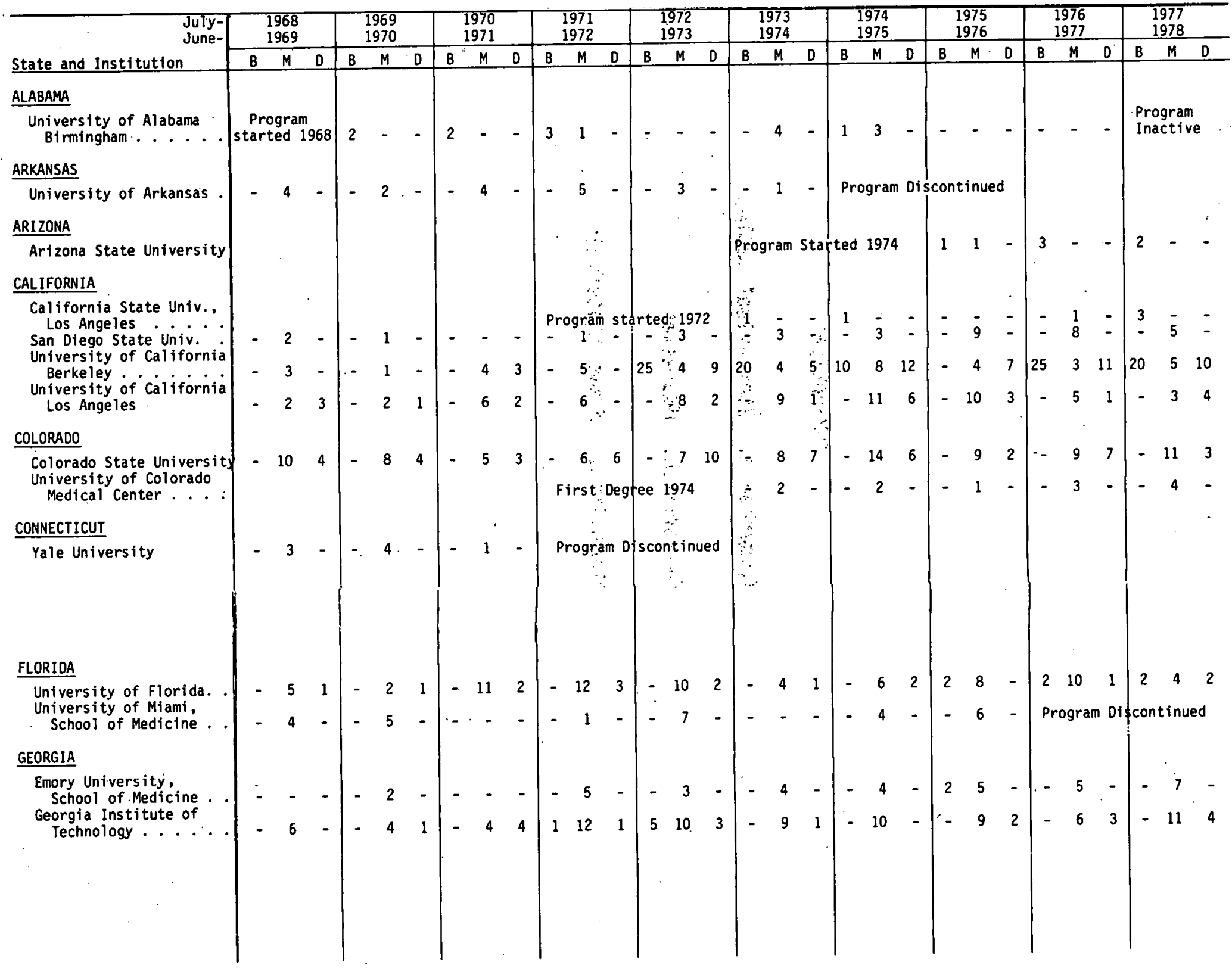




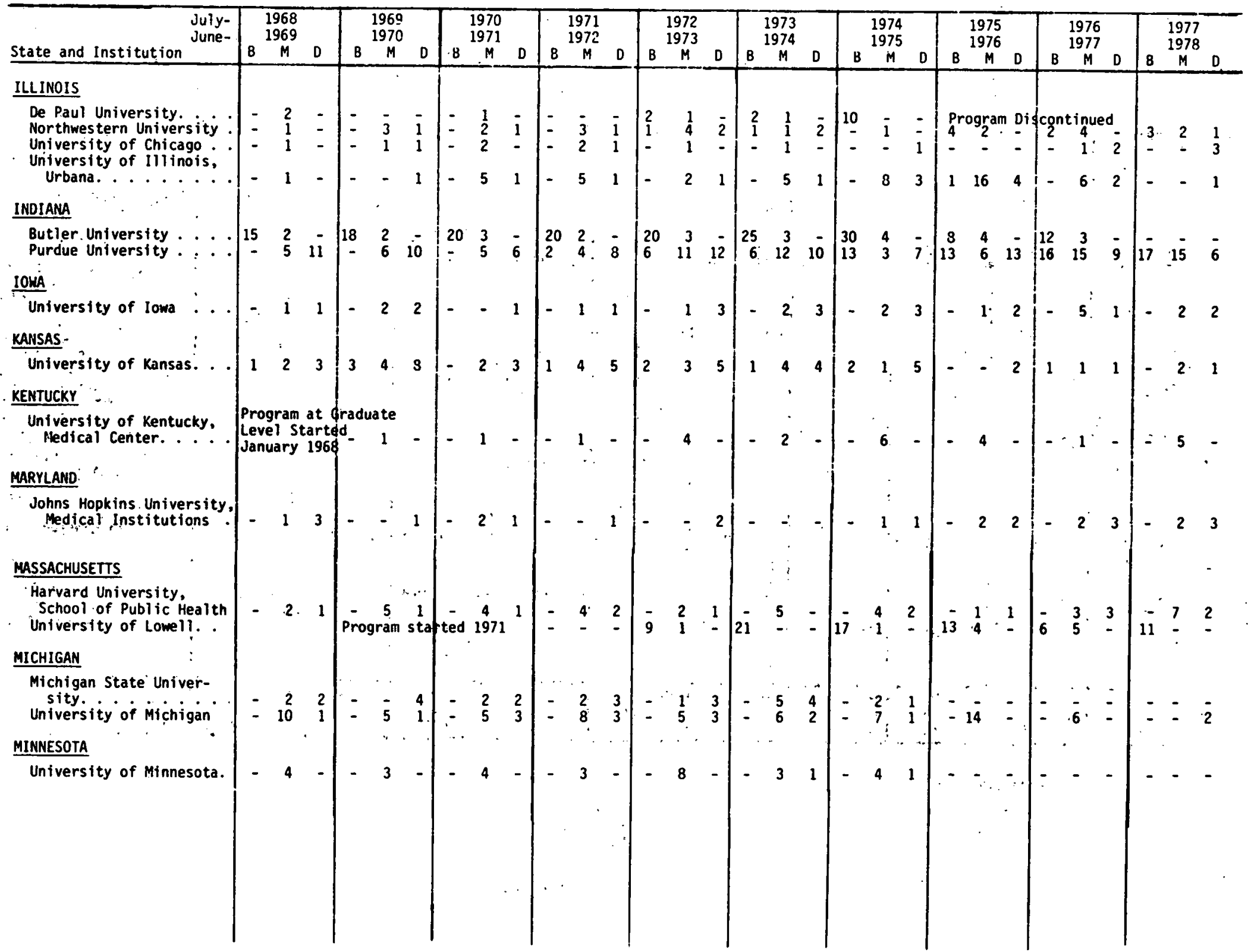




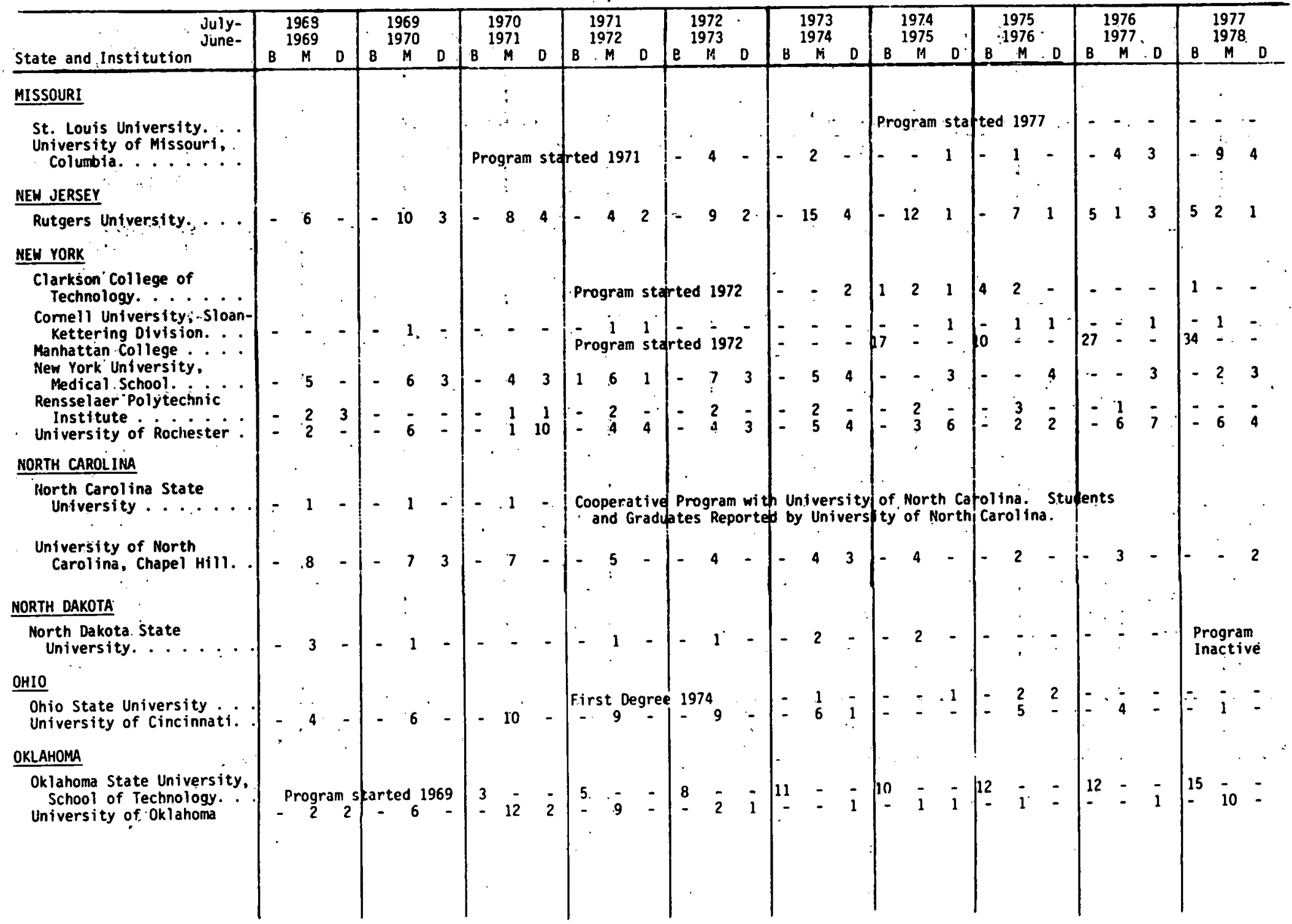




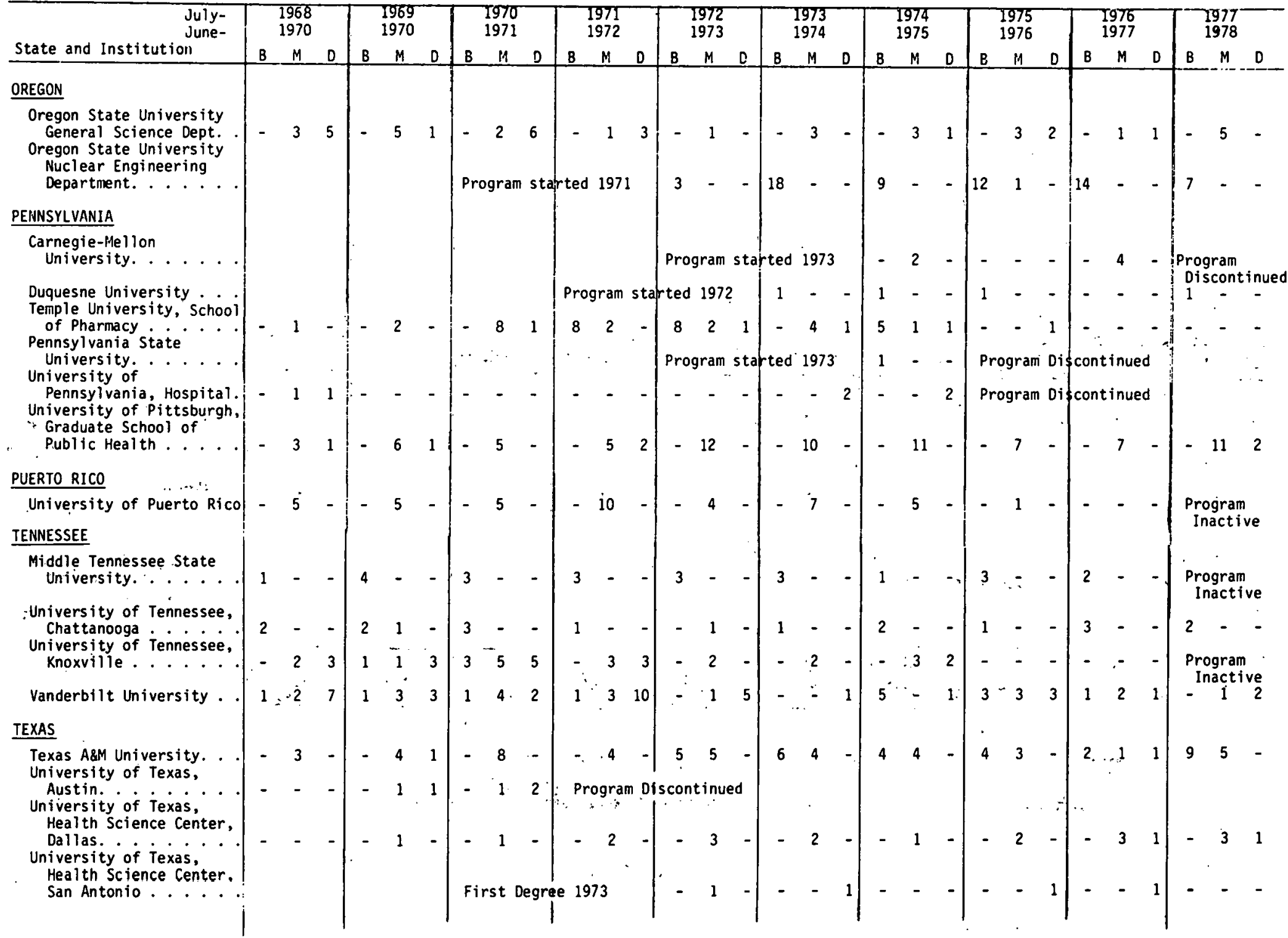


APPENDIX A-1

RAMIATION PROTFC.TION DEGREES GRANTED 1968- 1978

$B=$ Bachelors By Institution
B

$M=$ Masters

$D=$ Doctorate

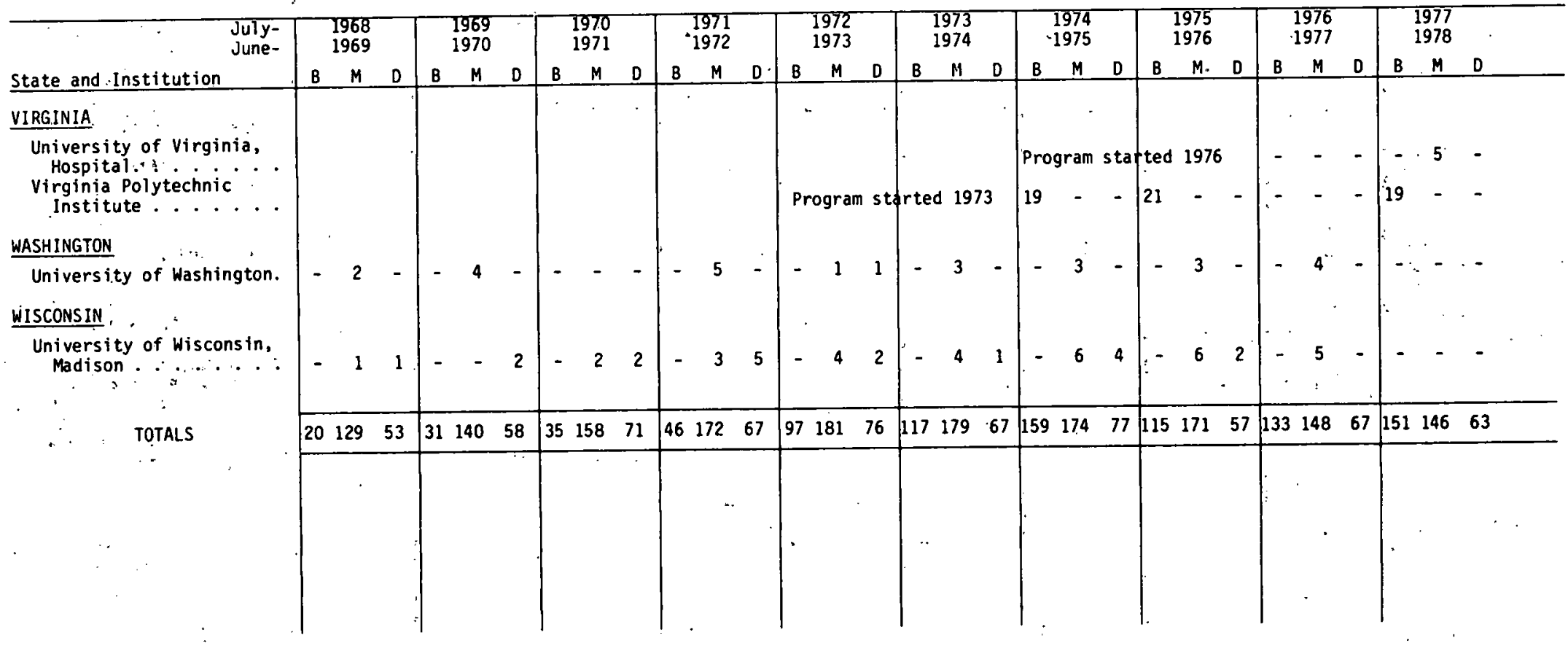


APPENDIX A-2

ENROLLMENTS ANO DEGREES IN SUBFIELOS BY INSTITUTION

RADIATION PROTECTION

$F T=F U L L$ TIME

PT = PART TIME

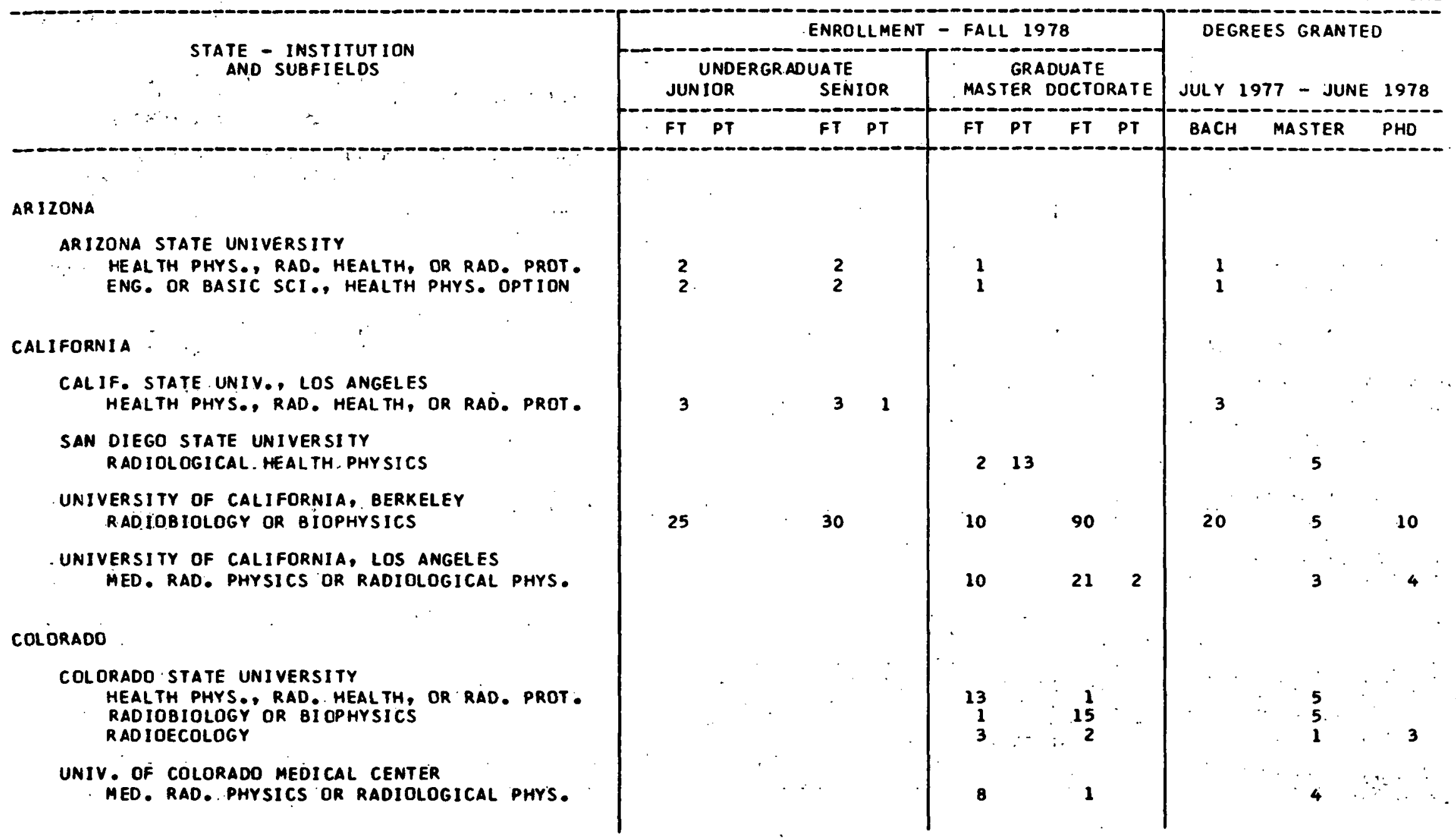


APPENDIX A-2 (CONT INUEO)

ENROLLMENTS AND DEGREES IN SUBFIELDS BY INSTITUTION

RADIATION PROTECTION

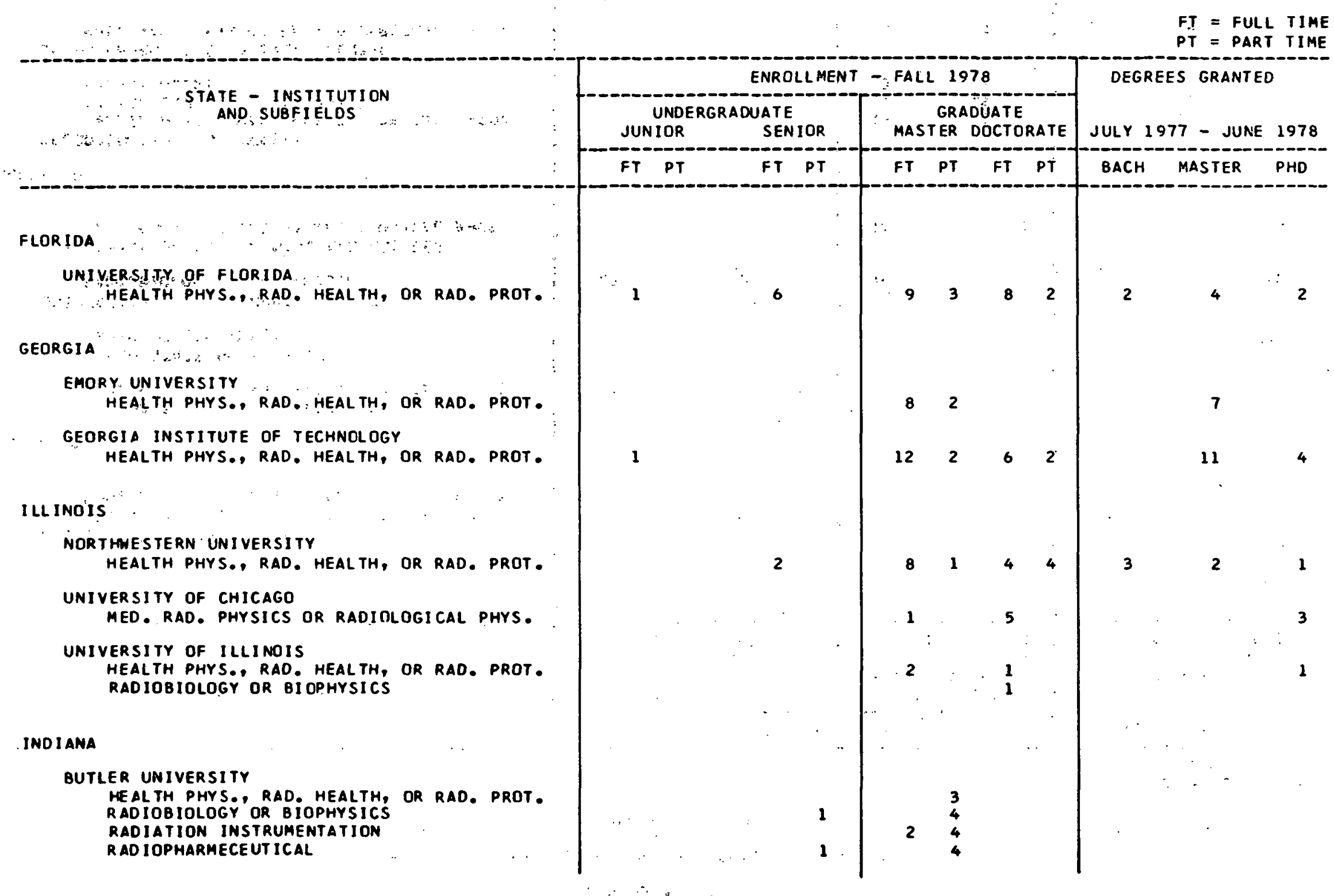


APPENDIX A-2 (CONT INUED)

.ENROLLMENTS AND DEGREES IN SUBF IELDS BY INSTITUTION

RADIATION PROTECTION

FT = FULL TIME

PT = PART TIME

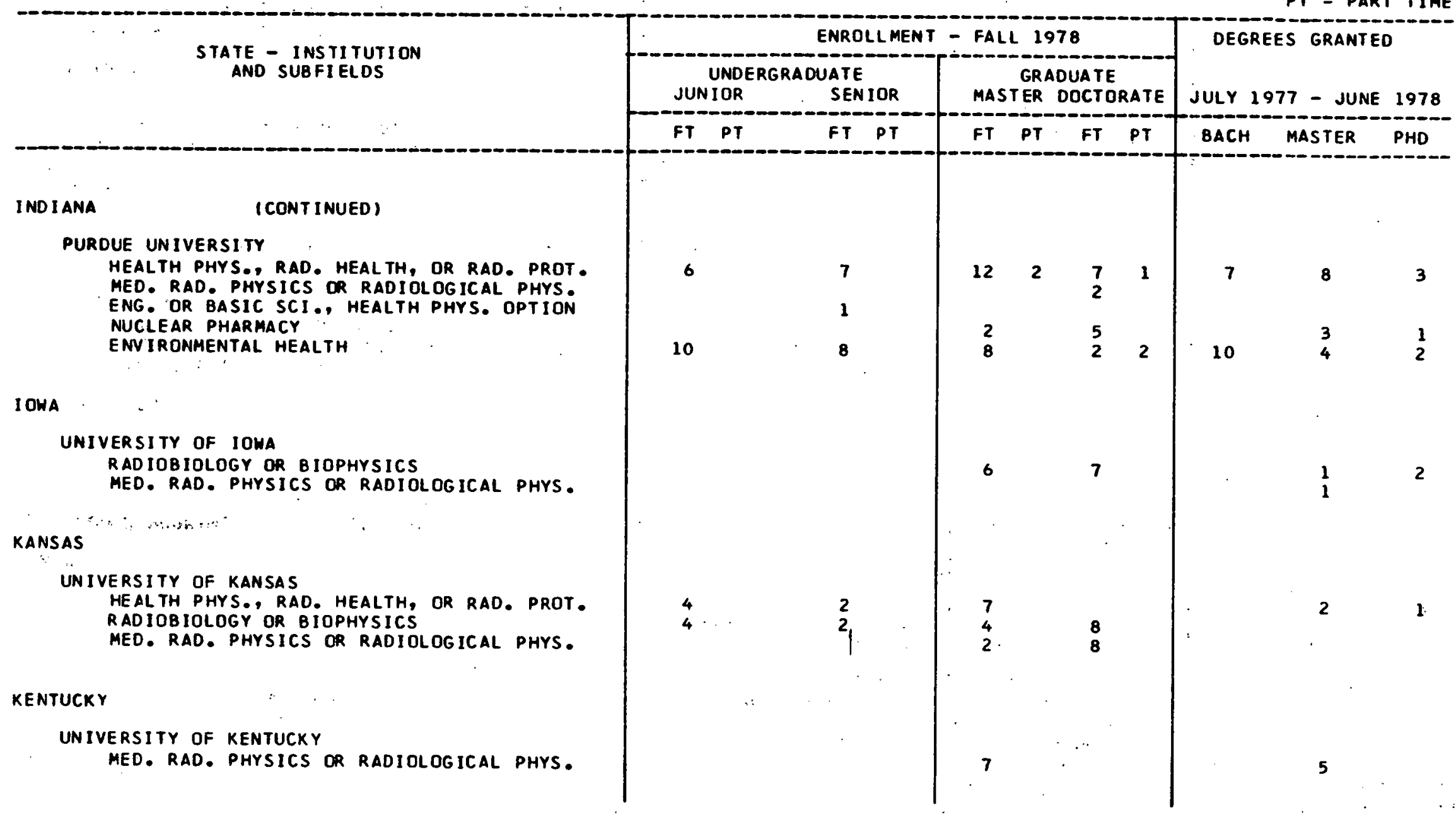


APPENDIX A-2 (CONTINUED)

ENROLLMENTS AND DEGREES IN SUBFIELOS BY INSTITUTION

RADIATION PROTECTION

$F T=$ FULL TIME

PT = PART TIME

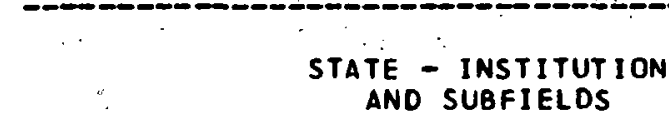
AND SUBFIELOS

JOHNS HOPKINS UN. SCH. PUB: HEALTH RAD IOBIOLOGY OR BIOPHYSICS

MED. RAD. PHYSICS OR RADIOLOGICAL PHYS. ENG. OR BASIC SCI., MEALTH PHYS. OPTION

MASSACHUSETTS

HARVARD SCHOOL OF PUBLIC HEALTH

HEALTH PHYS., RAD. HEALTH, OR RAD. PROT

RADIOBIOLOGY OR BIOPHYSICS

MED $\therefore$ RAD. PHYSICS OR RADIOLOGICAL. PHYS.

UNIVERSITY OF LOWELL

HEALTH PHYS. RAD. HEALTH, OR RAD. PROT.

\section{MICHIGAN}

UN IVERSITY OF MICHIGAN

HEALTH PHYS., RAD. HEALTH, OR RAD. PROT.

\section{MINNESOTA}

UNIVERSITY OF MINNESOTA

HEALTH PHYS.; RAD.-HEALTH, OR RAD: PROT.

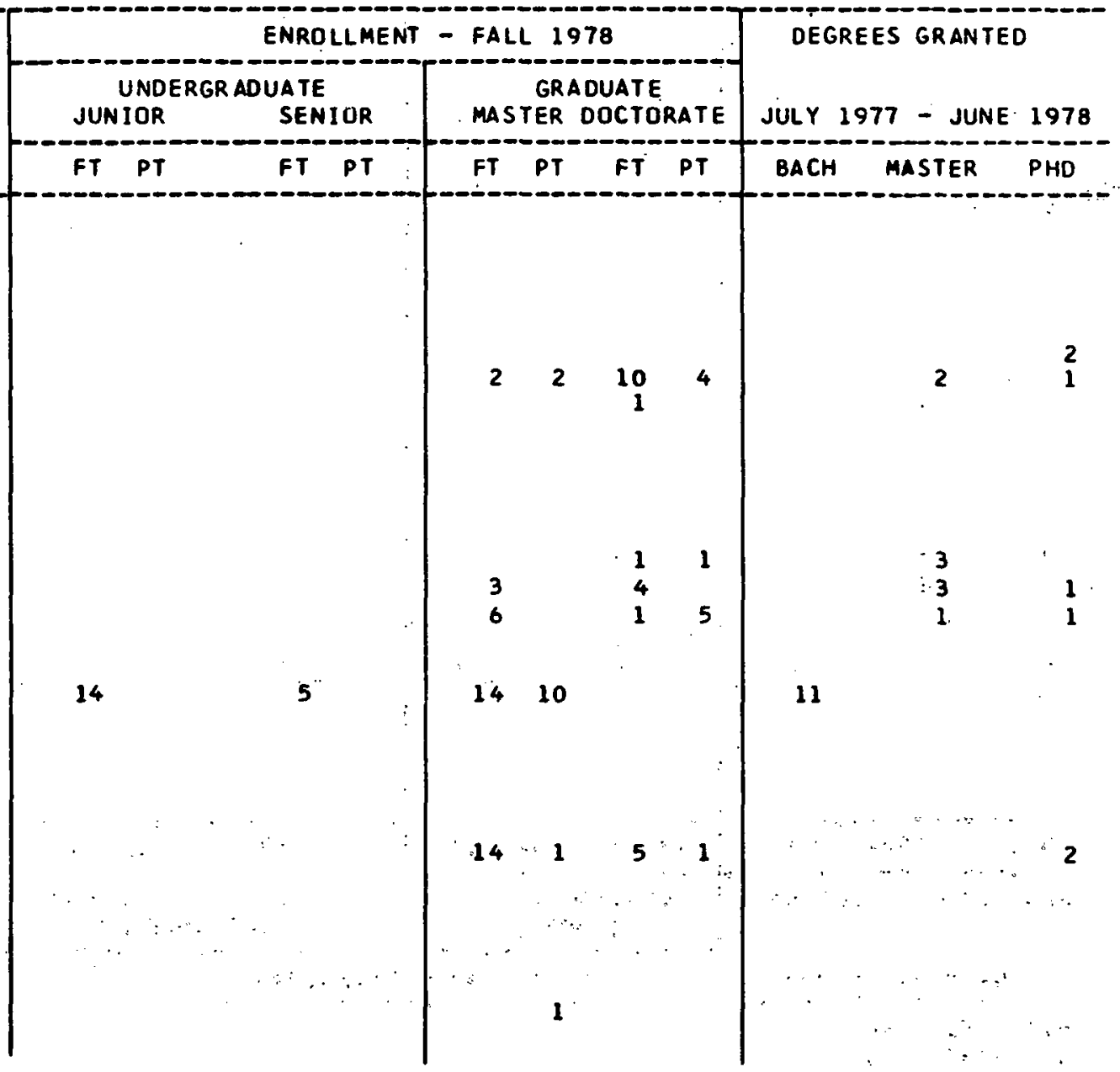


APPENDIX A-2 (CONTINUED)

ENROLLMENTS AND DEGREES IN SUBFIELOS BY INSTITUTION

RADIATION PROTECTION

$F T=F U L L$ TIME

PT = PART TIME

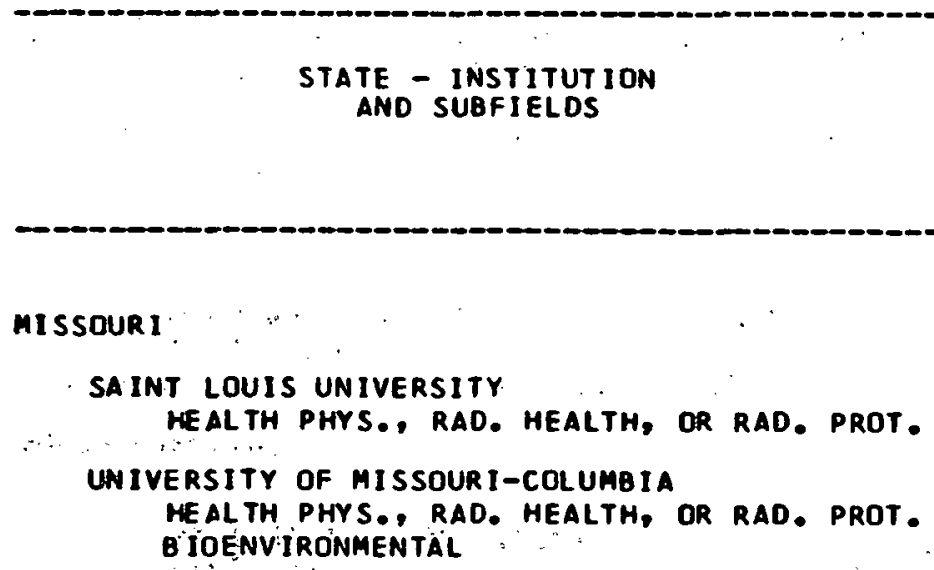

NEW JERSEY

RUTGERS UNIVERSITY

HEALTH PHYS: RAD. HEALTH, OR RAD, PROT. MED. RAD. PHYSICS OR RADIOLOGICAL PHYS. RADIATION CHEMISTRY

AEROSOL PHYSICS

NE'W YORK

CLARK SON COLLEGE

HEALTH PHYS., RAD. HĖALTH, OR RAD. PROT.

MED. RAD. PHYSICS OR RADIOLOGICAL PHYS.

CORNELL UNIVERSITY, SLOAN-KETTERING DIVISION RADIOBIOLOGY OR BIOPHYSICS

MED. RAD. PHYSICS OR RADIOLOGICAL PHYS.

MANHATTAN COLLEGE

RADIOLOGICAL AND HEALTH SCIENCES

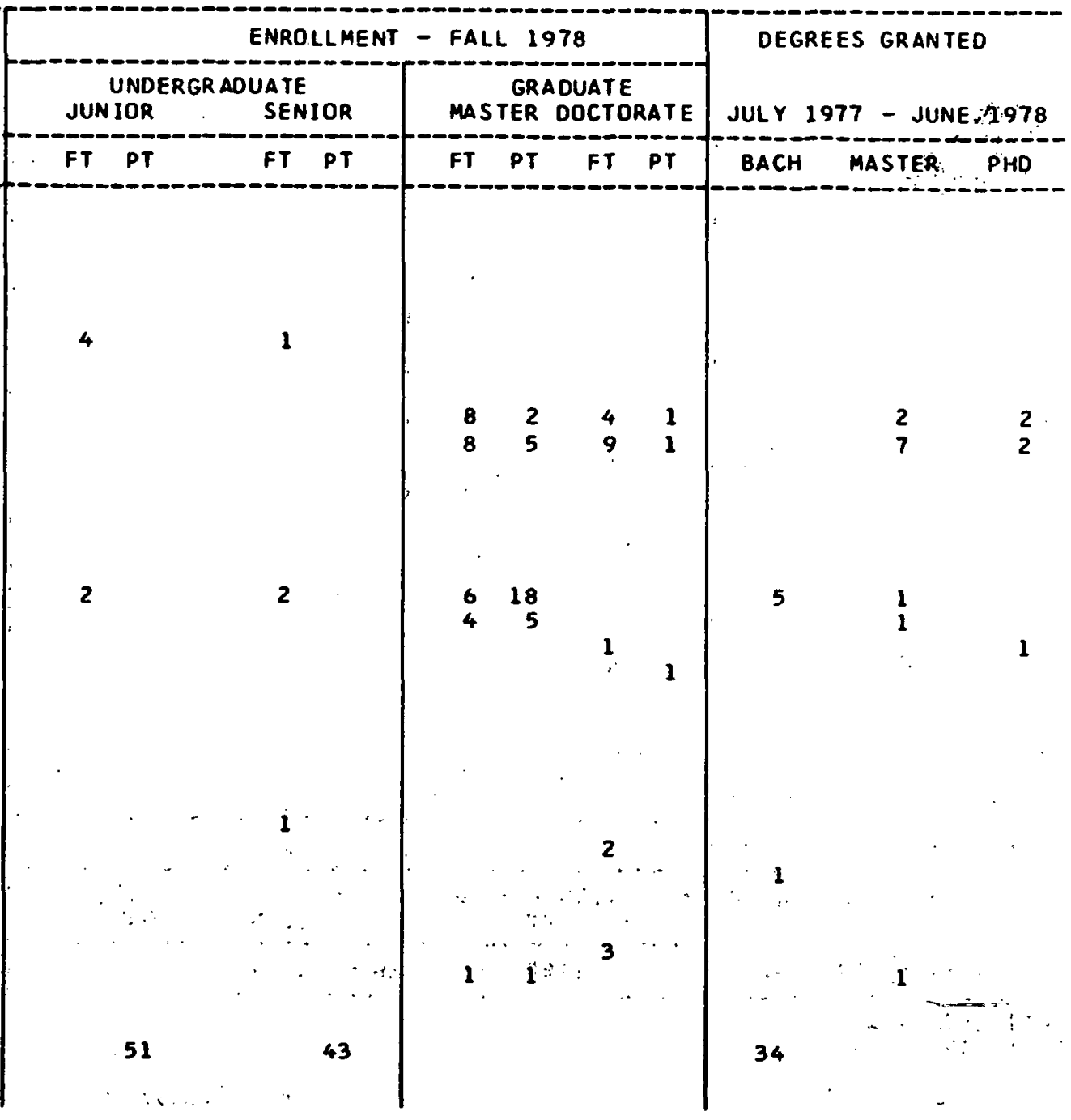


APPENDIX A-2 (CONT INUED)

ENROLLMENTS AND DEgREES IN SUBFIELDS BY INSTITUTION

RADIATION PROTECTION

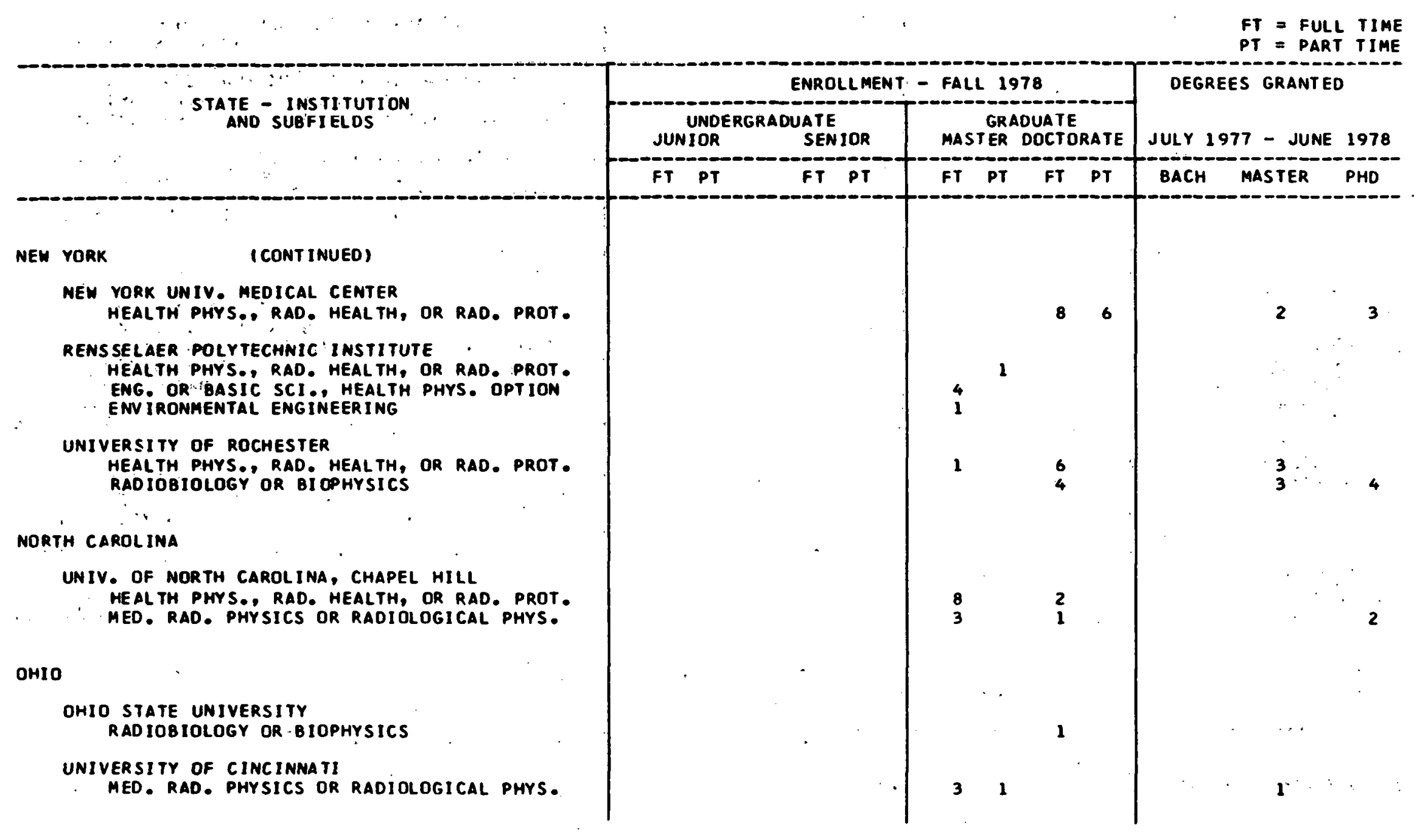


APPENDIX A-2 (CONT INUEO)

ENROLLMENTS AND DEGREES IN SUBFIELDS BY INSTITUTION

RAOIATION PROTECTION

$F T=F U L L$ TIME

$P T=P A R T$ TIME

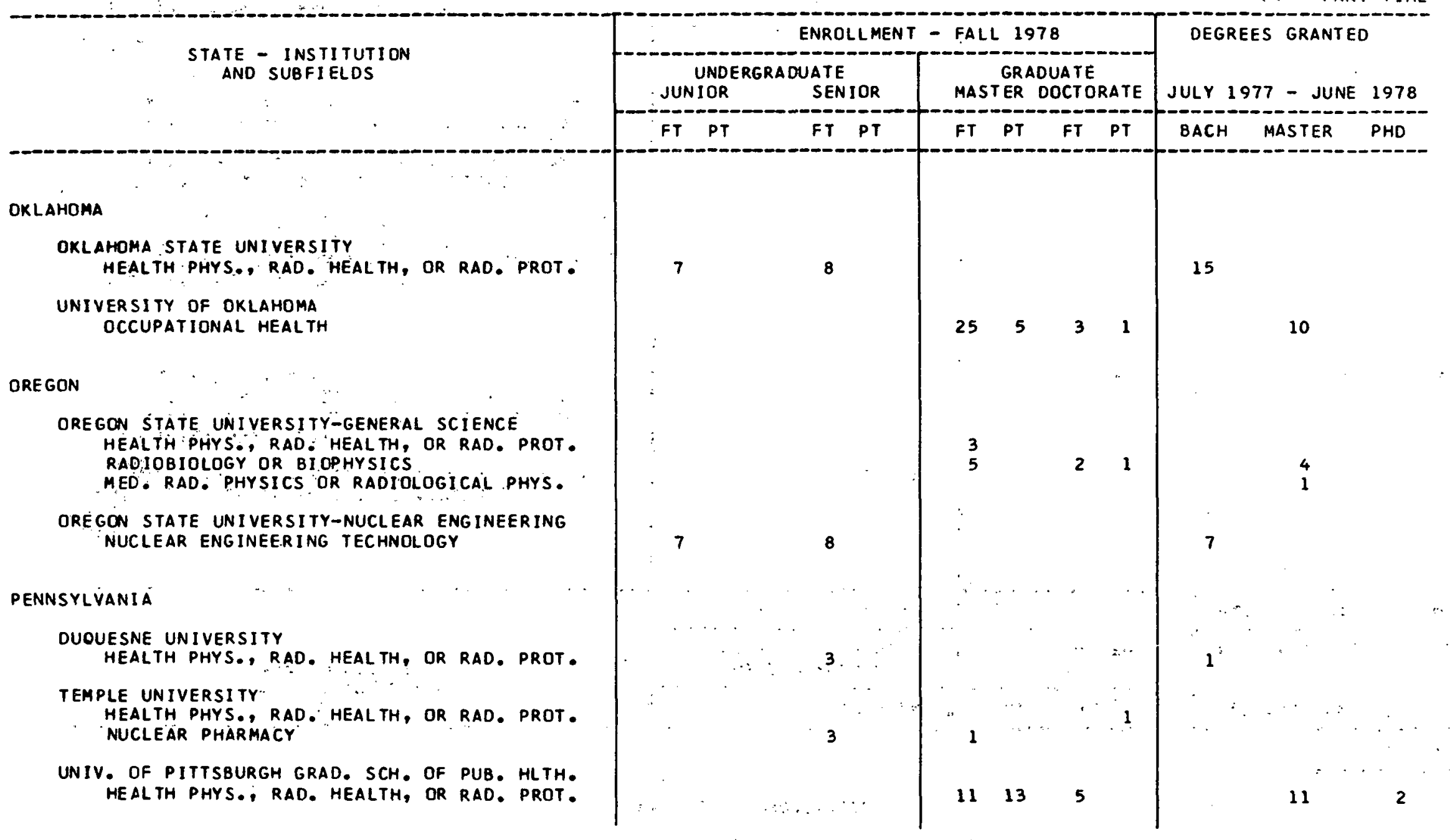


APPENDIX A-2 (CONTINUED)

ENROLLMENTS AND DEGREES IN SUBFIELOS BY INSTITUTION

RADIATION PROTECTION

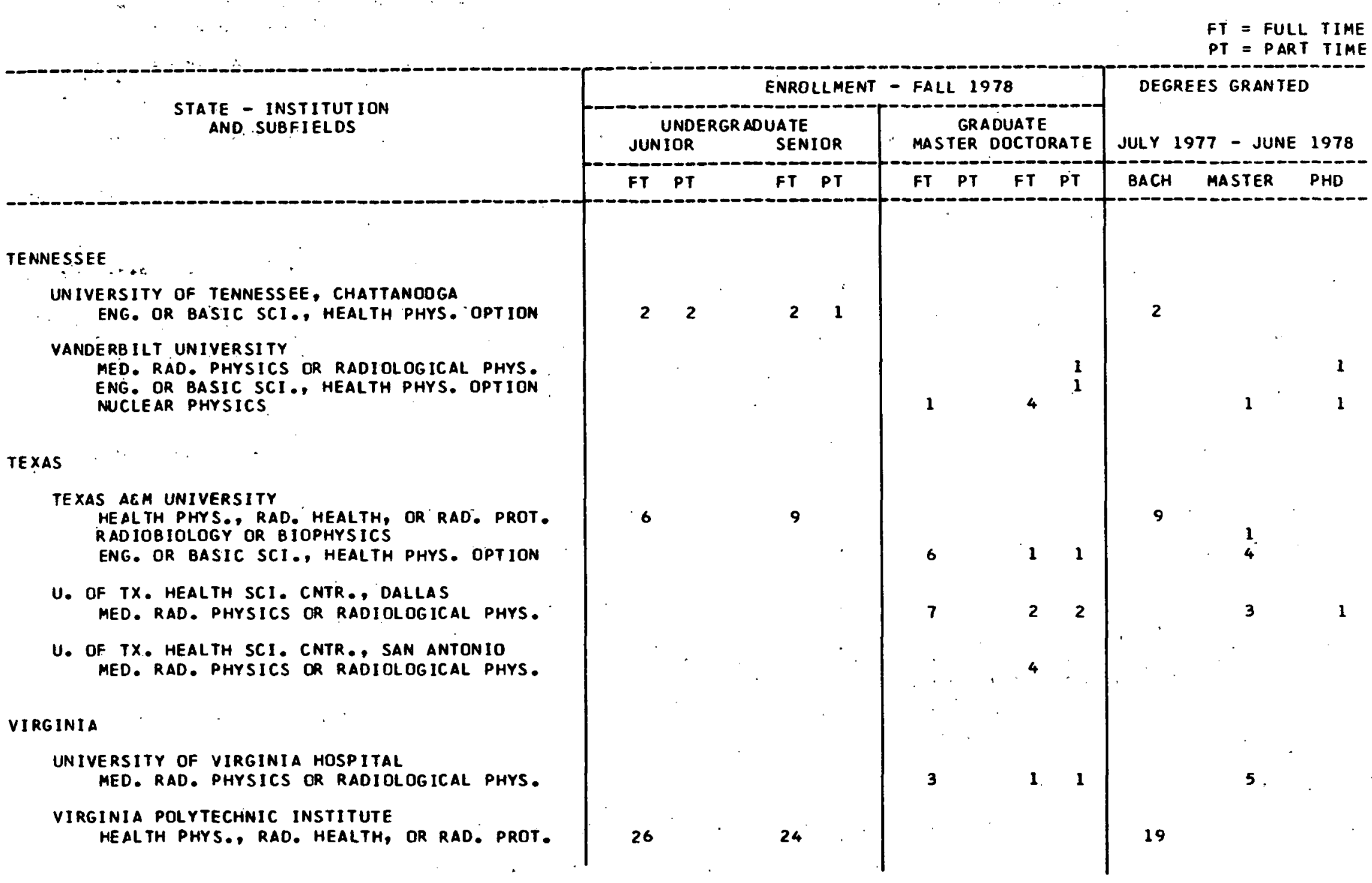


APPENDIX A-2 (CONTINUED).

ENROLLMENTS AND DEGREES IN SUBFIELDS BY INSTITUTION

RADIATION PROTECTION

$=$ FULL TIME

PT = PART TIME

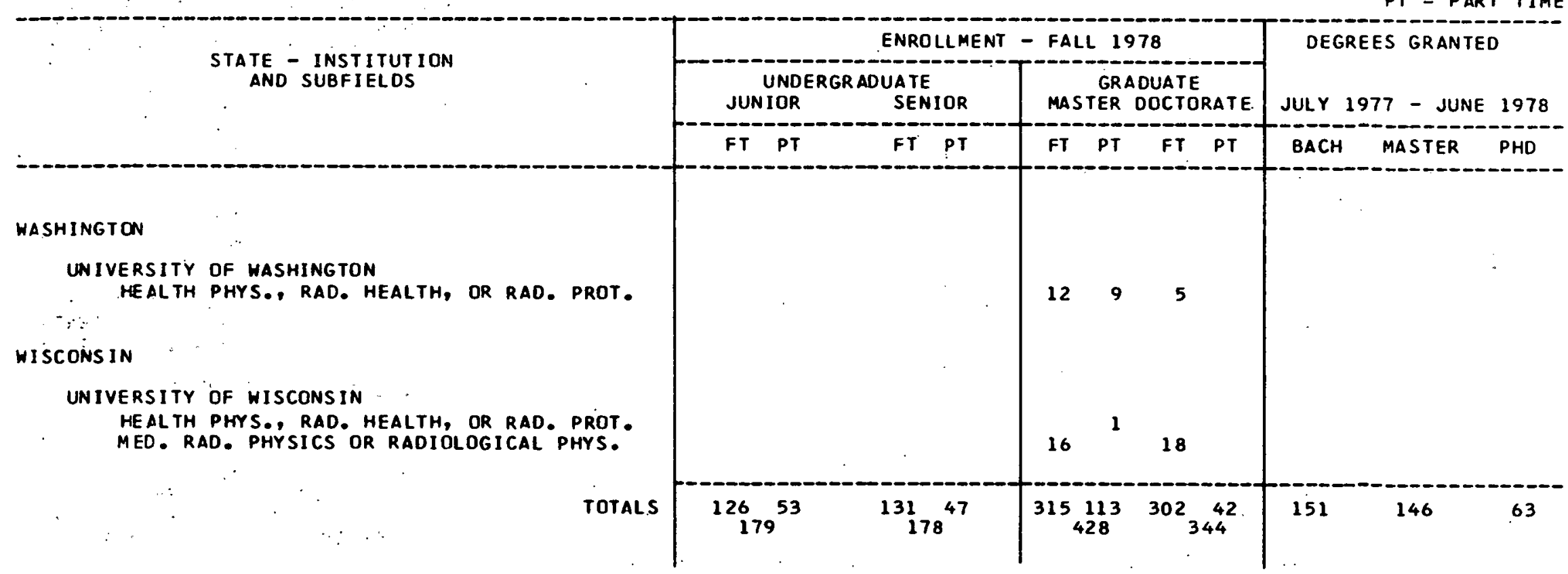
HEALTH PHYS. RAD. HEALTH, OR RAD. PROT
MED. RAD. PHYSICS OR RADIOLOGICAL PHYS.

TOTALS

$179^{5}$

178 
APPENDIX A-3

MINORITIES, WOMEN AND FOREIGN NATIONALS

ENROLLMENTS AND DEGREES BY INSTITUTION

RADIATION PROTECTION

$F T=F U L L$ TIME
PT = PART TIME

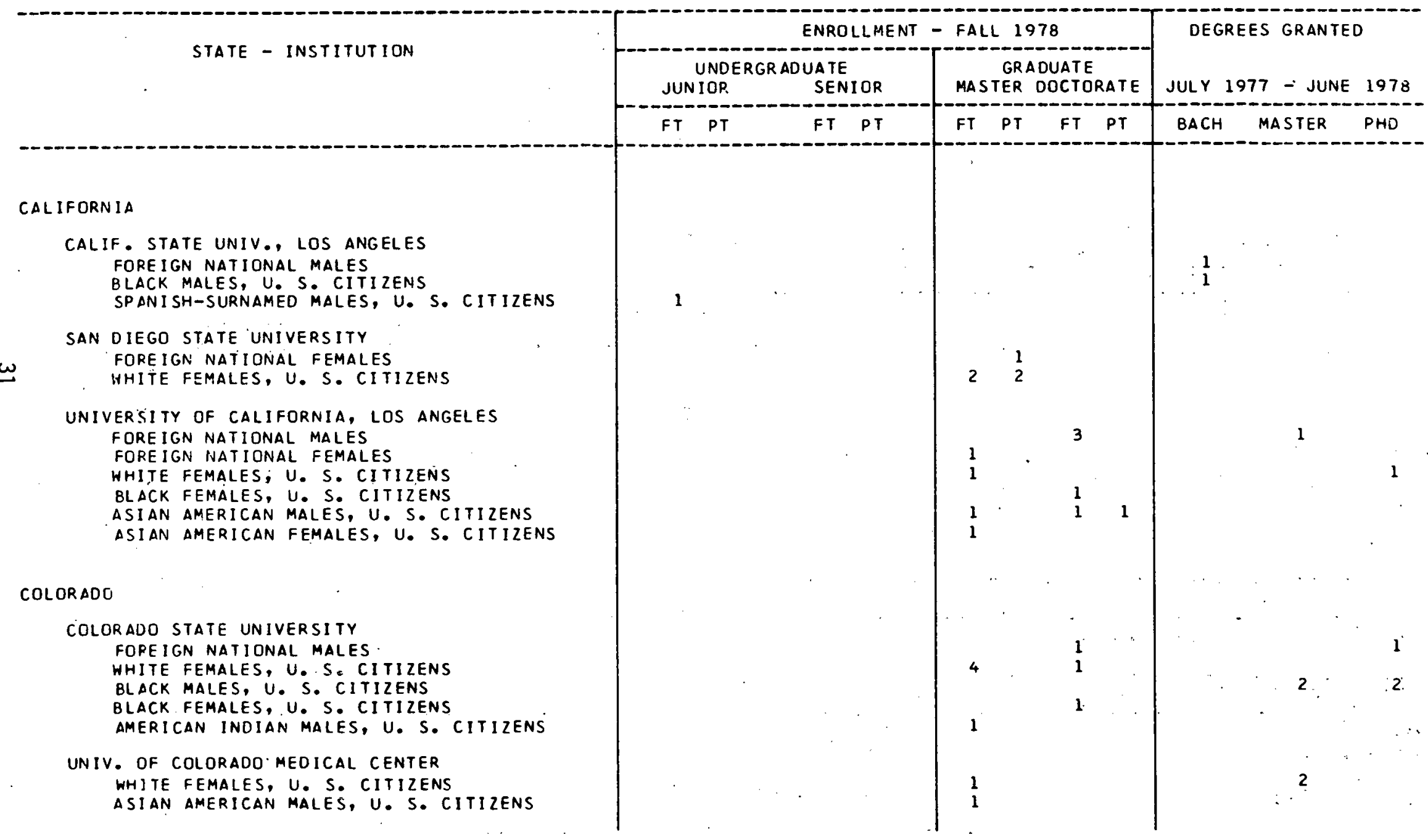


APPENDIX A-3 (CONT INUEO)

MINORITIES, WOMEN ANO FOREIGN NATIONALS

ENROLLMENTS AND DEGREES BY INSTITUTION

RADIATION PROTECTION

$F T=F U L L \quad T I M E$

PT $=$ PART TIME

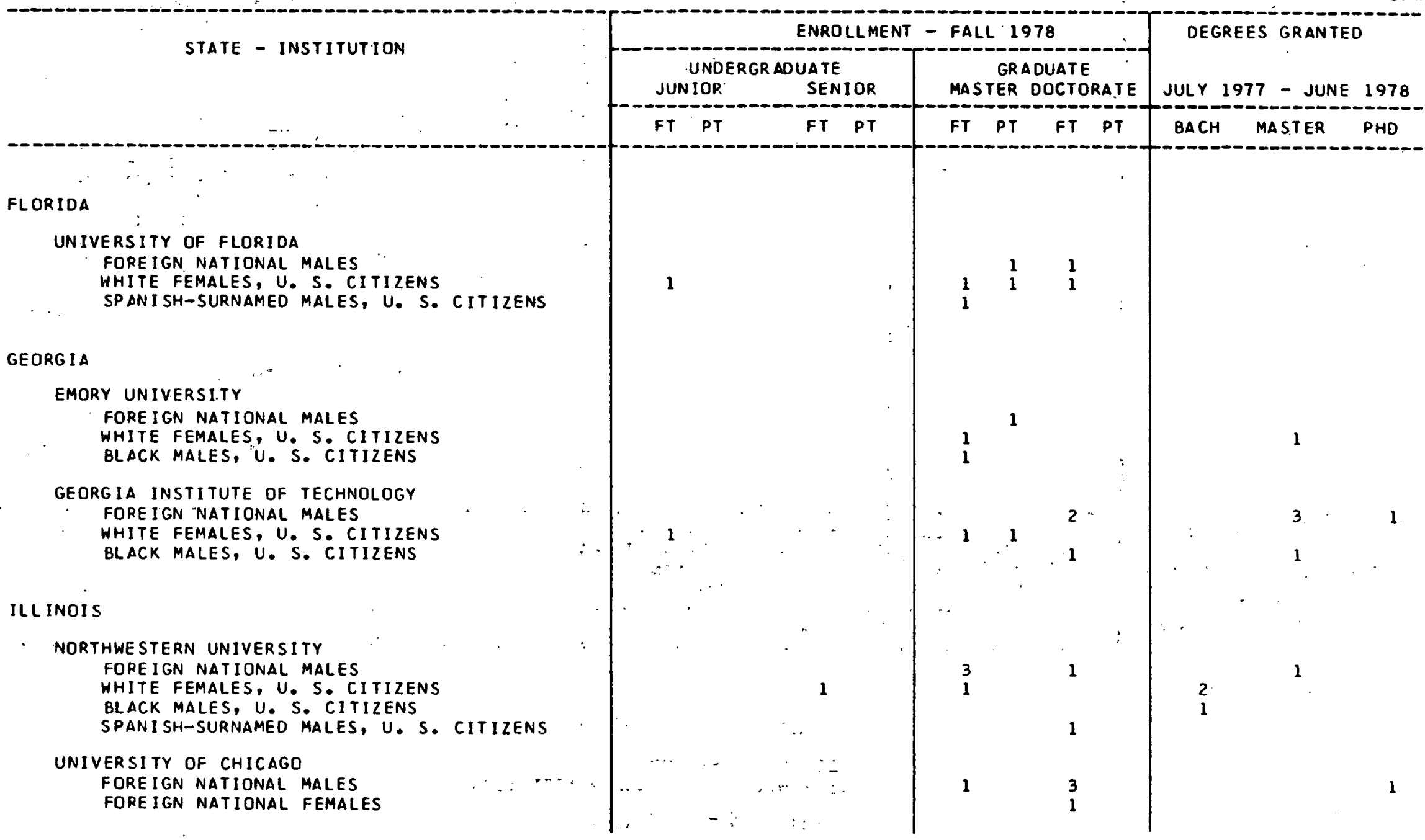


APPENDIX A-3 (CONTINUED)

MINORITIES, WOMEN AND FORE IGN NATIONALS

ENROLLMENTS AND DEGREES BY INSTITUTION

RADIATION PROTECTION

$F T=F U L L ~ T I M E$

PT = PART TIME

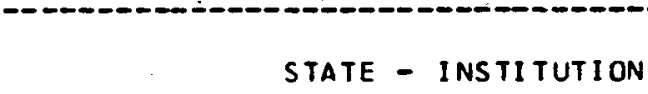

STATE - INSTITUTION

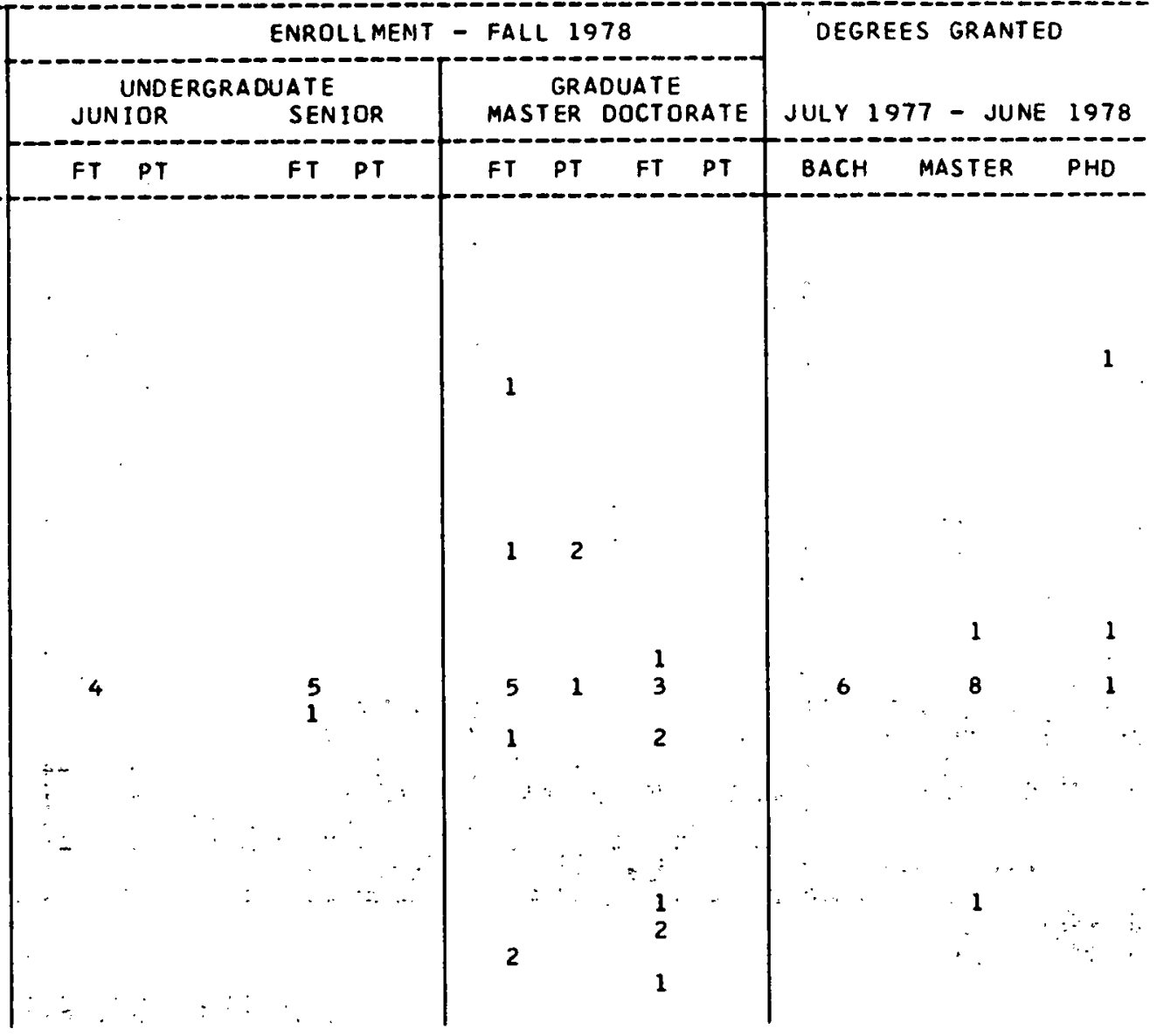

$\omega$

IND 1 ANA

BUTLER UNIVERSITY

WHITE FEMALES, U. S. CITIZENS

PURDUE UNIVERSITY

FOREIGN NATIONAL MALES

FORE IGN NATIONAL FEMALES

WHITE FEMALES, U. S. CITIZENS

WHITE FEMALES, U. S. CITIZENS

ASIAN AMERICAN FEMALES, U. S. CITIZENS

IOWA

UNIVERSITY OF IOWA

FORE IGN NATIONAL MALES

FOREIGN NATIONAL FEMALES

WHITE FEMALES, U. S. CITIZENS

SPANISH-SURNAMED MALES, U. S. CITIZENS

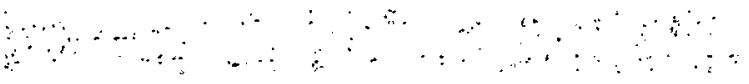


APPENDIX A-3 (CONT INUED)

MINORITIES, WOMEN AND FOREIGN NATIONALS

ENROLLIMENTS AND DEGREES BY. INSTITUTION

RADIATION PROTECTION

$F T=F U L L$ TIME

PT = PART TIME

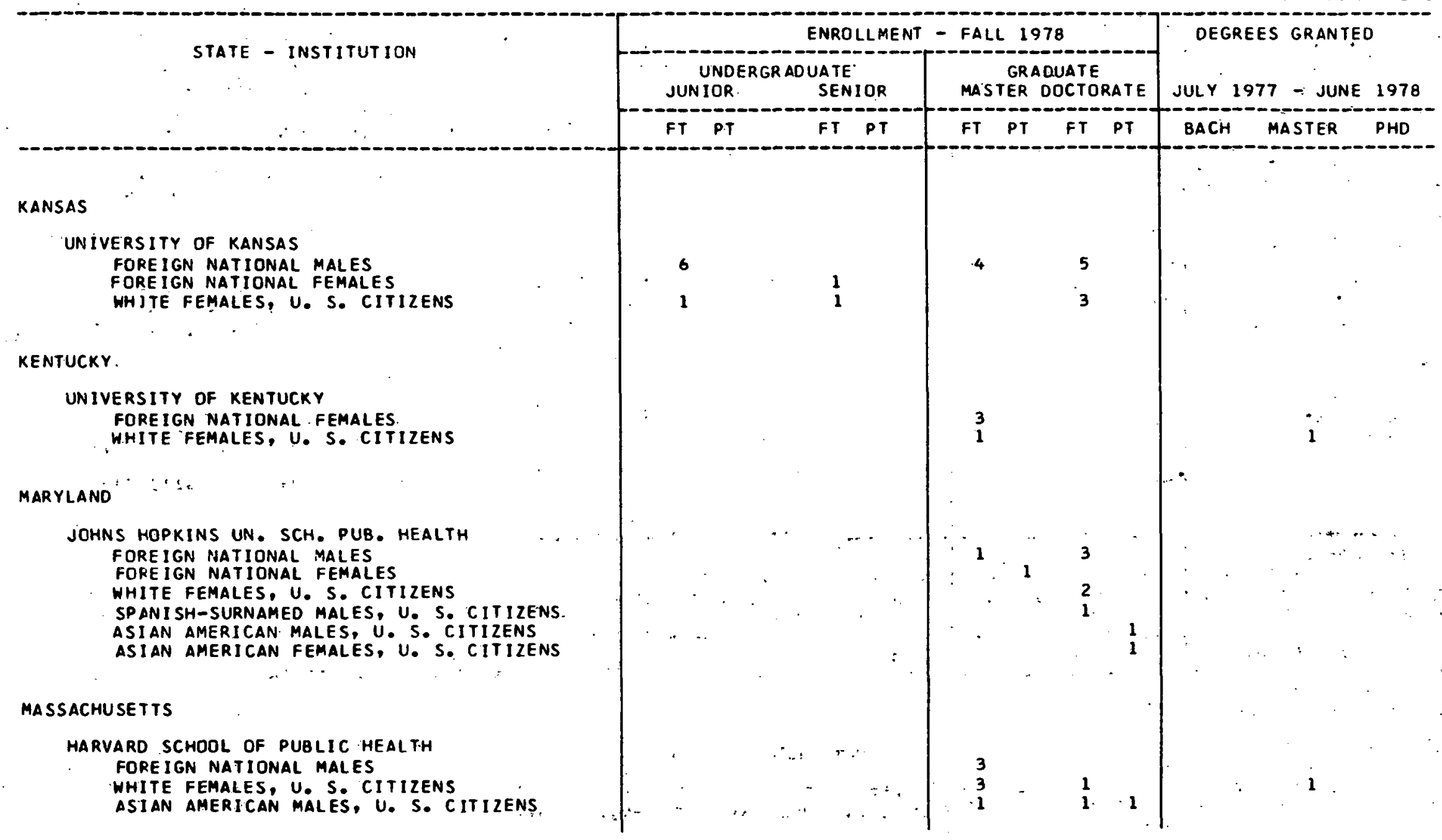


APPENDIX A-3 (CONTINUED)

MINORITIES, WOMEN AND FOREIGN NATIOMALS

ENROLLMENTS ANO DEGREES BY INSTITUTION

RADIATION PROTECTION

$F T=F U L L T I M E$

PT = PART TIME

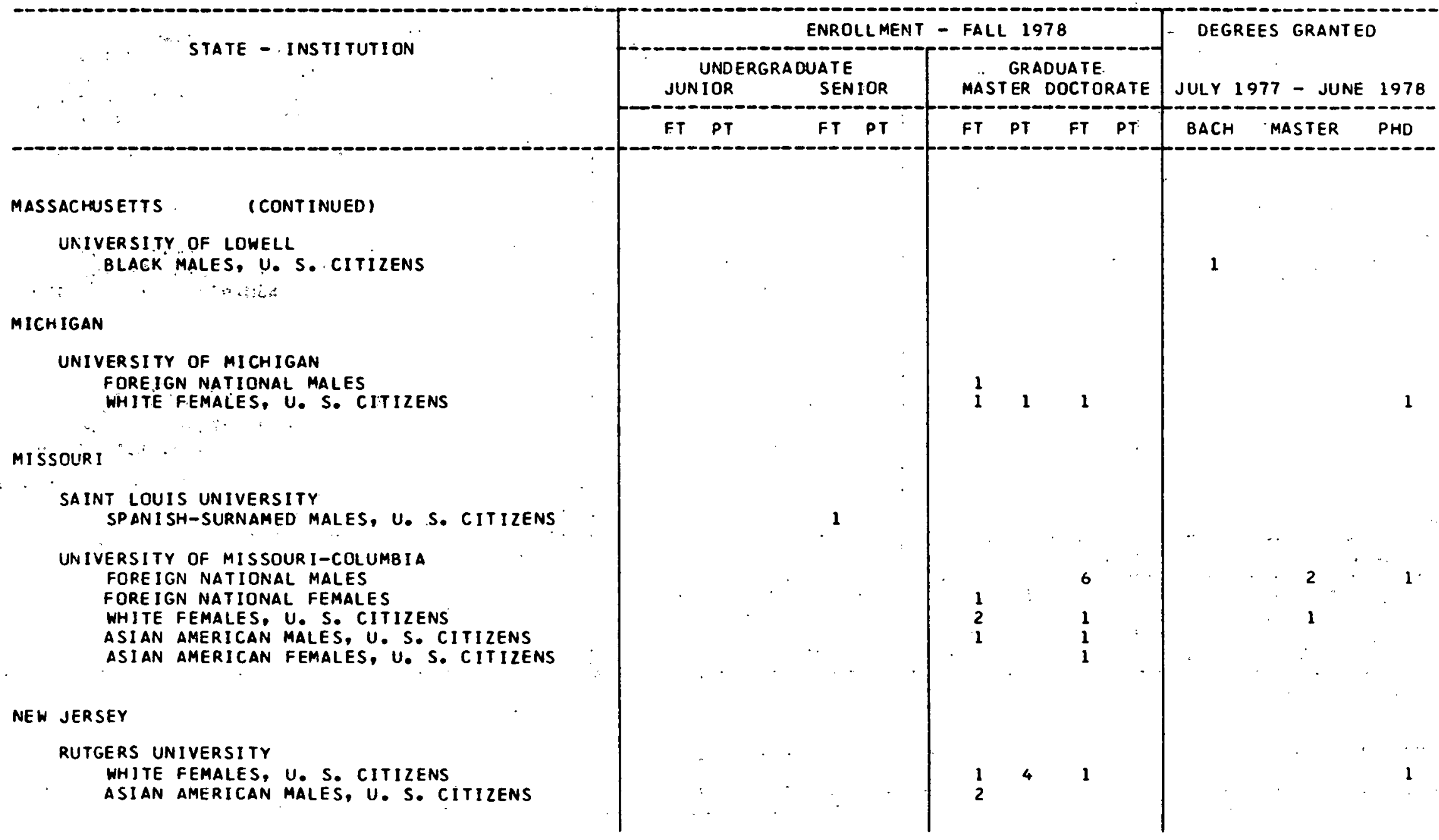


APPENDIX A-3 (CONT INUED)

MINORITIES, WOMEN AND FOREIGN NATIONALS ENROLLMENTS AND DEGREES BY INSTITUTION

RADIATION PROTECTION

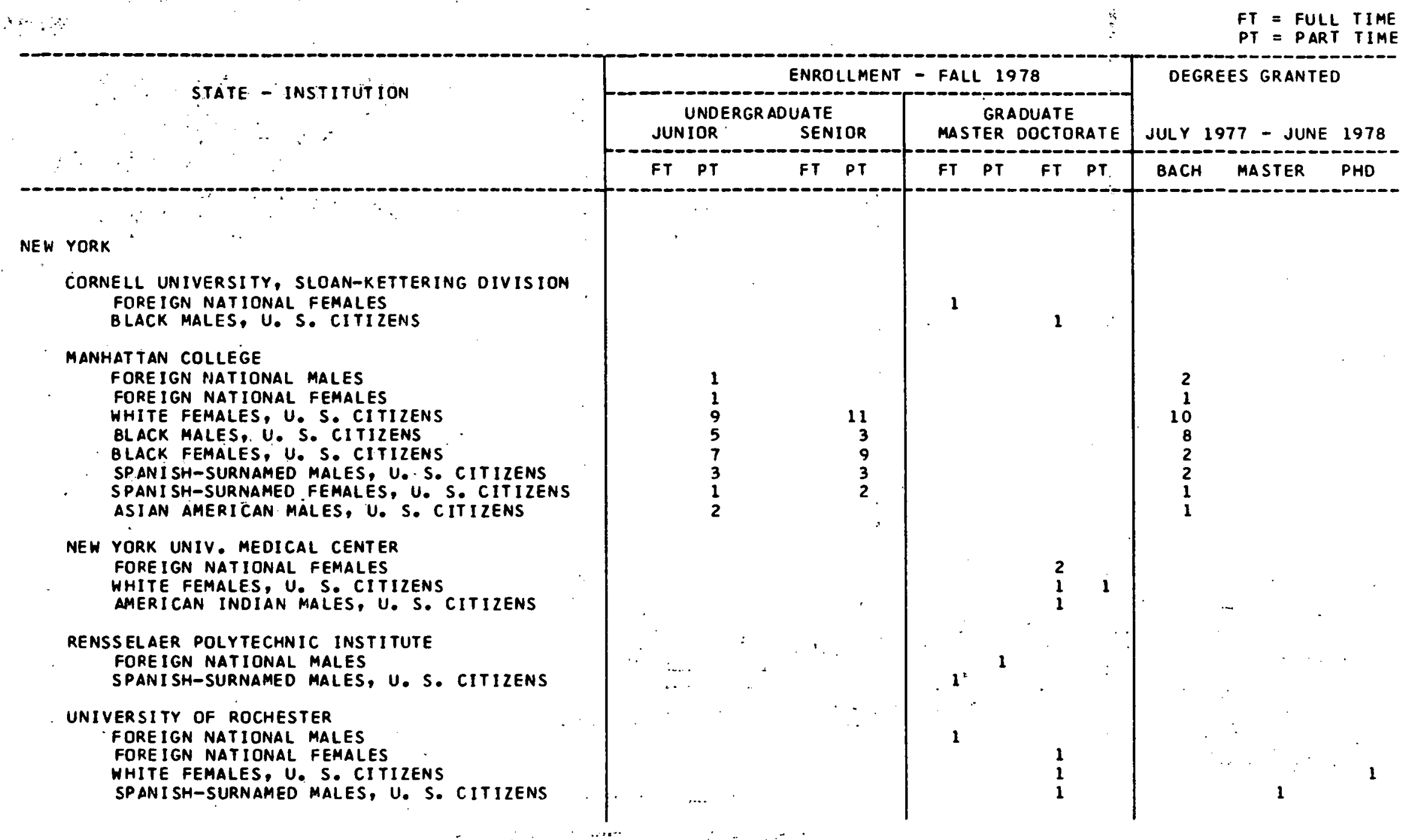


APPENDIX A-3 (CONTINUED)

MINORITIES, WOMEN AND FOREIGN NATIOMALS ENROLLMENTS AND DEGREES BY INSTITUTION

RADIATION PROTECTION

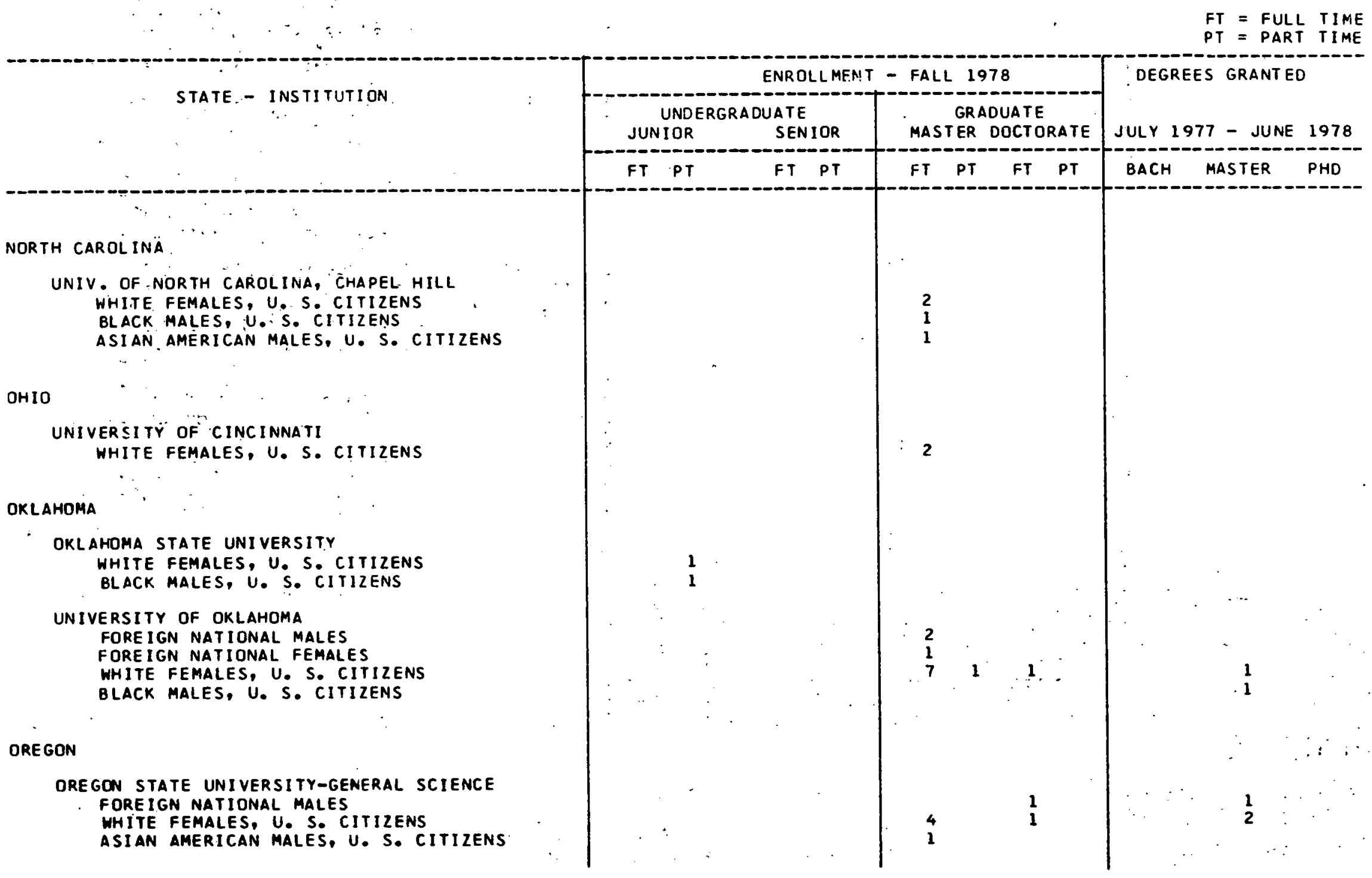


APPENDIX A-3 (CONT INUED)

MINORITIES, WOMEN AND FOREIGN NATIONALS

ENROLLMENTS AND DEGREES BY INSTITUTION

RADIATION PROTECTION

$F T=F U L L \quad T I M E$

PT = PART TIME

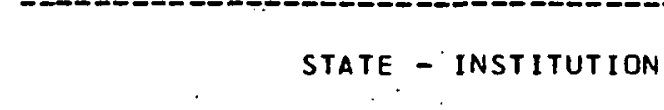

(CONTINUED)
OREGON STATE UNIVERSITY-NUCLEAR ENGINEERING
FOREIGN NATIONAL MALES
WHITE.FEMALES, U. S. CITIZENS

$\stackrel{\omega}{\infty}$

\section{PENNSYLVANIA}

DUOUESNE UNIVERSITY

WHITE FEMALES, U. S. CITIZENS

TEMPLE UNIVERSITY

WHITE FEMALES, U. S. CITIZENS

\section{TENNESSEE}

VANDERBILT UNIVERSITY

FOREIGN NATIONAL MALES

TEXAS:

-TEXAS AEM UNIVERSITY

FOREIGN NATIONAL MALES

BLACK MALES,. U. S. CITIZENS

U. OF TX. MEALTH SCI. CNTR ., DALLAS FORE IGN NATIONAL MALES

FOREIGN NATIONAL FEMALES

WHITE FEMALES, U. S. CITIZENS

as

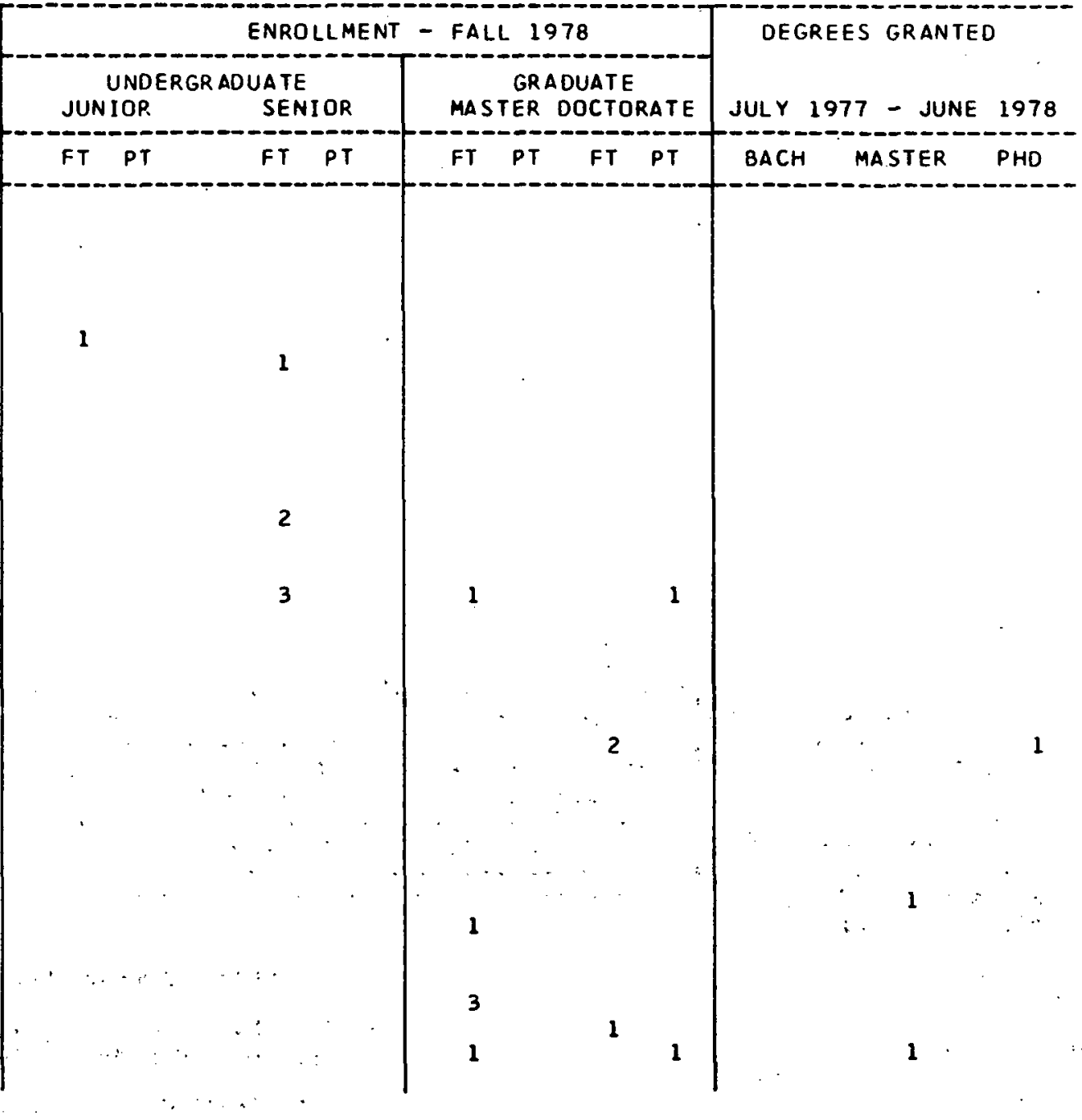


APPENDIX A-3 (CONTINUED)

MINORITIES, WOMEN : ANO FOREIGN NATIONALS

ENROLLMENTS ANO DEGREES BY INSTITUTION.

RADIATION PROTECTION

FT = FULL TIME

PT = PART TIME

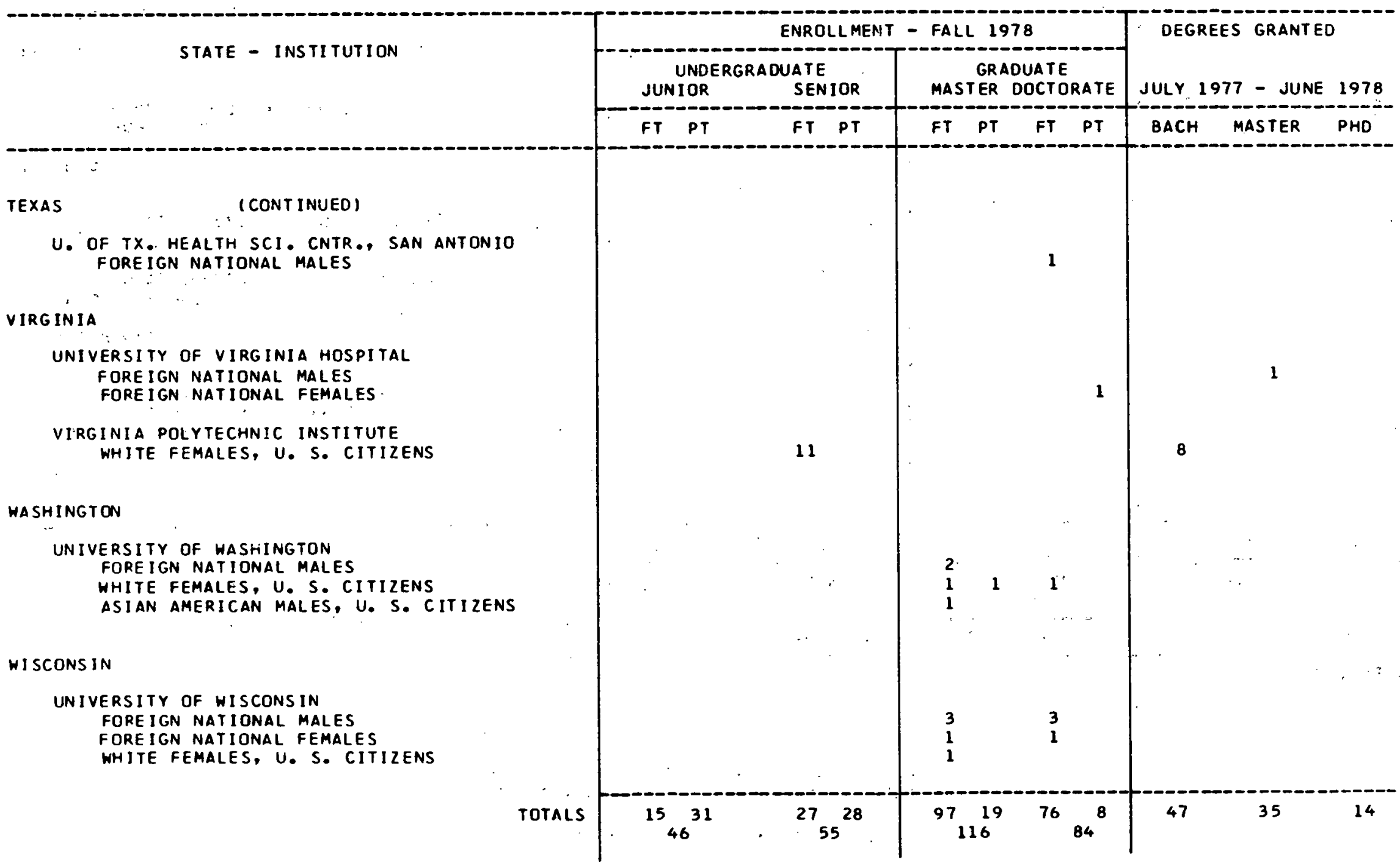


APPENDIX $A-4$

RADIATION PROTECTION CURRICULUM

OR OPTIONS BY UNDERGRADUATE OR GRADUATE INSTITUTION

FALL 1978

HEALTH PHYSICS, RADIATION HEALTH OR RADIATION PROTECTION UNDERGRADUATE

GRADUATE

Arizona State University. . . . . . . . . . . . . Arizona State University

California State University

San Diego State University

Colorado State University

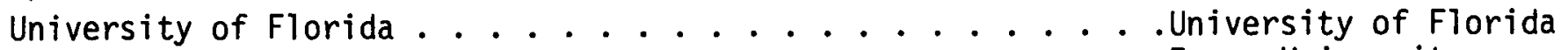

Emory University

Georgia Institute of Technology . . . . . . . . . . Georgia Institute of Technology

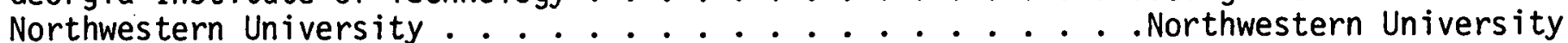

University of Illinois

Butler University

Purdue University . . . . . . . . . . . . . . . . Purdue University

University of Kansas. ....................... University of Kansas

Harvard School of Public Health

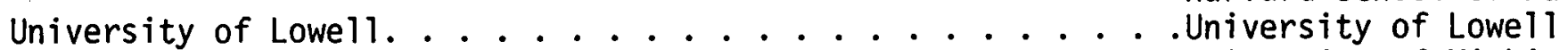

University of Michigan

Saint Louis University

University of Minnesota

Rutgers University. . . . . . . . . . . . . Rutgers University

Clarkson College

New York University, Medical Center

Rensselaer Polytechnic Institute

University of Rochester

Oklahoma State University

University of North Carolina, Chapel Hill

Duquesne University

Oregon State University

Temple University

University of Pittsburgh, Graduate School of Public Health

Texas A\&M University

Virginia Polytechnic Institute 
OR OPTIONS BY UNDERGRADUATE OR GRADUATE INSTITUTION

FALL 1978

RADIOBIOLOGY OR BIOPHYSICS

\section{UNDERGRADUATE}

GRADUATE

University of California, Berkeley. . . . . . . . University of California, Berkeley. Colorado State University University of II]inois

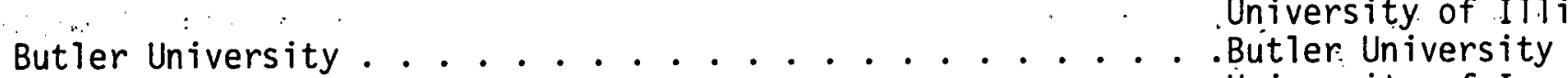

University of Iowa

University of Kansas. . . . . . . . . . . . . University of Kansas

Johns Hopkins University School of

Public Health

Harvard School of Public Health

Clarkson College

Cornell University, Sloan-Kettering Division University of Rochester

Ohio State University

Oregon State University

Texas. A\&M University

MEDICAL RADIATION PHYSICS OR RADIOLOGICAL. PHYSICS

University of California, Los Angeles University of Colorado Medical Center

University of Chicago

Purdue University

University of Kansas.

University of Kentucky

Johns Hopkins University School of

Public Health

Harvard School of Public Health

Rutgers University

Manhattan College

Cornell University, Sloan-Kettering Division 
APPENDIX A-4 (Continued)

RADIATION PROTECTION CURRICULUM

OR OPTIONS BY UNDERGRADUATE OR.GRADUATE INSTITUTION

FALL 1978

MEDICAL RADIATION PHYSICS OR RADIOLOGICAL PHYSICS (Continued)

GRADUATE

University of North Carolina, Chapel Hill University of Cincinnati

Vanderbilt University

University of Texas-Health Science Centêr, Dallas

University of Texas. Health Science

Center; San Antonio

University of Virginia Hospital

University of Wisconsin.

Arizona State University. . . . . . . . . . . . Arizona State University

Purdue University

University of Tennessee, Chattanooga."
Johns Hopkins University School of Public Health

Rensselaer Polytechnic Institute

Vanderbilt University

Texas A\&M University

AEROSOL PHYSICS

Rutgers University

BIOENVIRONMENTAL

University of Missouri, Columbia 
APPENDIX A-4 (Continued)

RADIATION PROTECTION CURRICULUM

OR OPTIONS BY UNDERGRADUATE OR GRADUATE INSTITUTION

FALL 1978

ENVIRONMENTAL ENGINEERING

UNDERGRADUATE

GRADUATE

Rensselaer Polytechnic Institute

ENVIRONMENTAL HËALTH

Purdue University. . . . . . . . . . . . . . . Purdue University

NUCLEAR ENGINEERING TECHNOLOGY

Oregon State University

NUCLEAR PHARMACY

Purdue University

Temple University. . . . . . . . . . . . . Temple University

NUCLEAR PHYSICS

Vanderbilt University

OCCUPATIONAL: HEALTH

University of Oklahoma

RADIATION CHEMISTRY

Rutgers University

RADIATION INSTRUMENTATION

Butler University 
$\because 3$

APPENDIX A-4 (Continued)

RADIATION PROTECTION CURRICULUM

OR OPTIONS BY UNDERGRADUATE OR GRADUATE INSTITUTION

FALL 1978

RADIOECOLOGY

UNDERGRADUATE

\section{GRADUATE}

Colorado State University

RADIOPHARMECEUTICAL

Butler University. ................. Butler University 
APPENDIX A-5

ENROLLMENTS AND DEGREES IN SUBFIELDS BY STATE AND REGION

RADIATION PROTECTION

FT = FULL TIME

PT = PART TIME

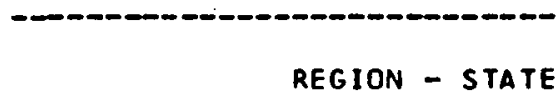

REGION - STATE

REGION I - NEH ENGLAND

MASSACHUSETTS

TOTAL

$\stackrel{G}{R}$

REGION 11 - MIDOLE ATLANTIC

NEH JERSEY

NEH YORK

PENNSYLVANIA

TOTAL

REGION III - EAST NORTH-CENTRAL

ILLINOIS

INDIANA

MICHIGAN

OHIO

WISCONSIN

TOTAL

REGION IV - WEST NORTH-CENTRAL

IOWA

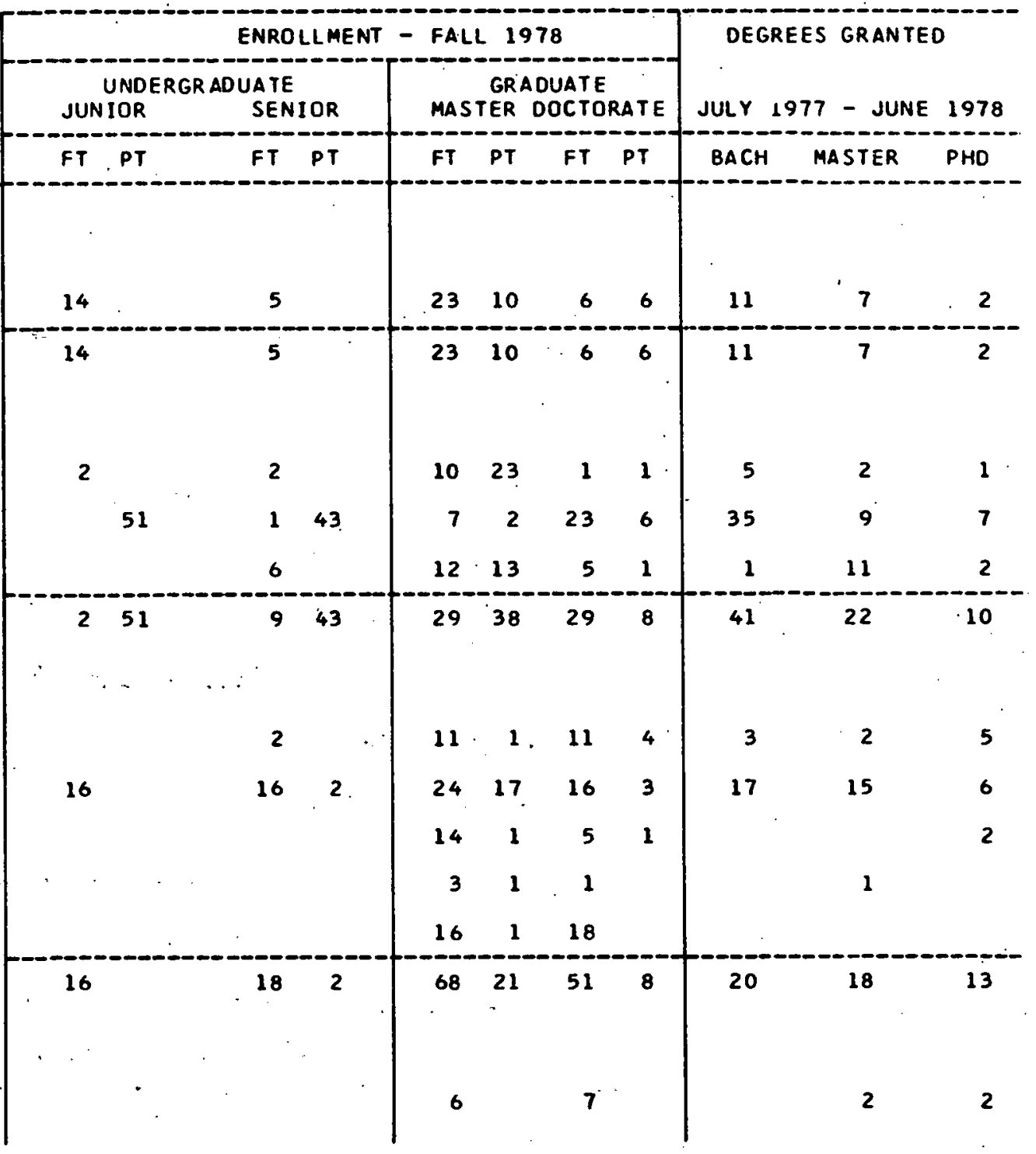


APPENDIX A-5 (CONT INUED)

ENROLLMENTS AND DEgREES IN SUBF IELDS BY STATE ANO REGION

RADIATION PROTECTION

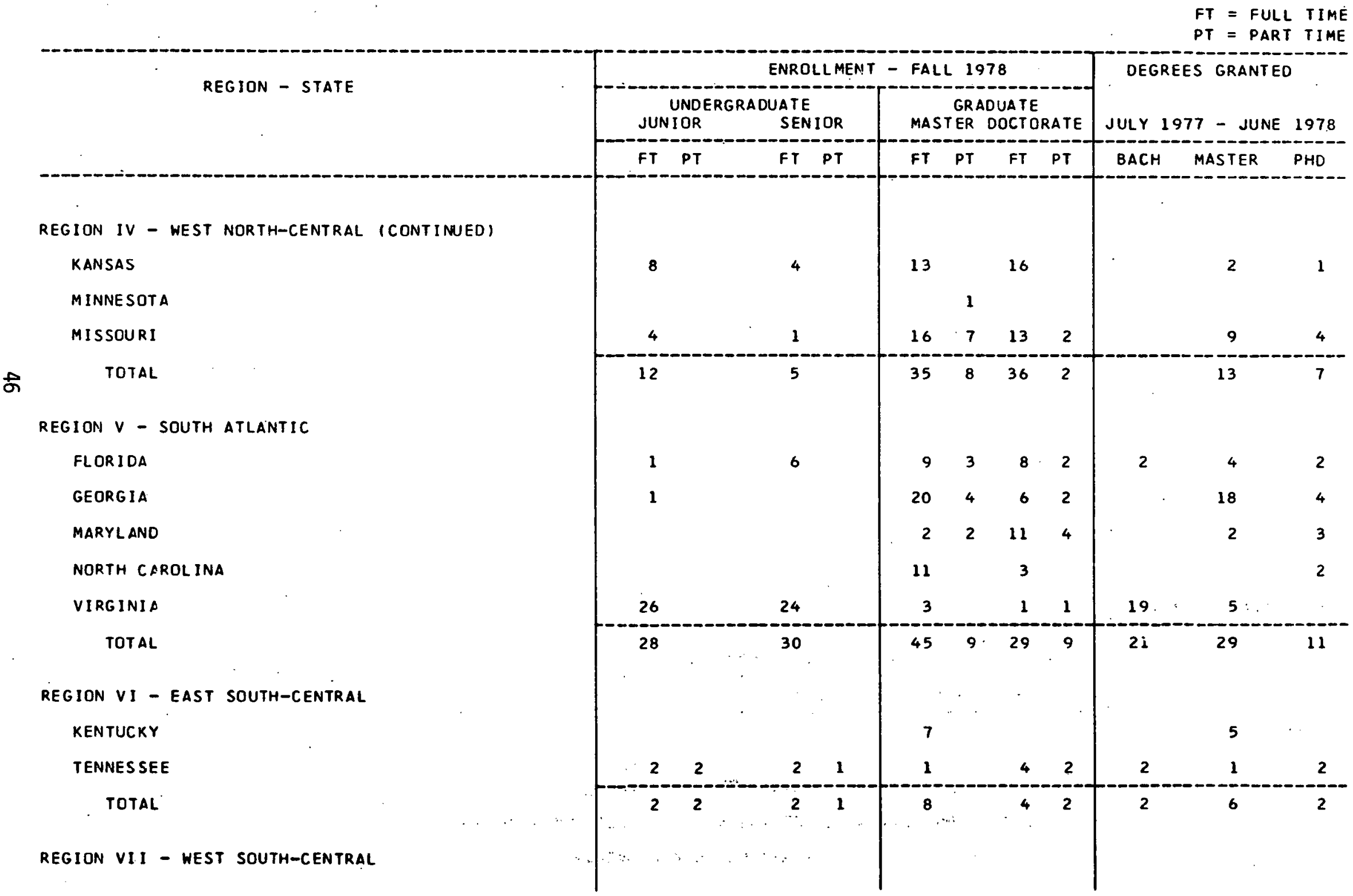


APPENDIX A-5 (CONT INUED)

ENROLLMENTS AND DEgREES IN SUBF IELDS BY STATE AND REGION RADIATION PROTECTION

$F T=$ FULL TIME PT = PART TIME

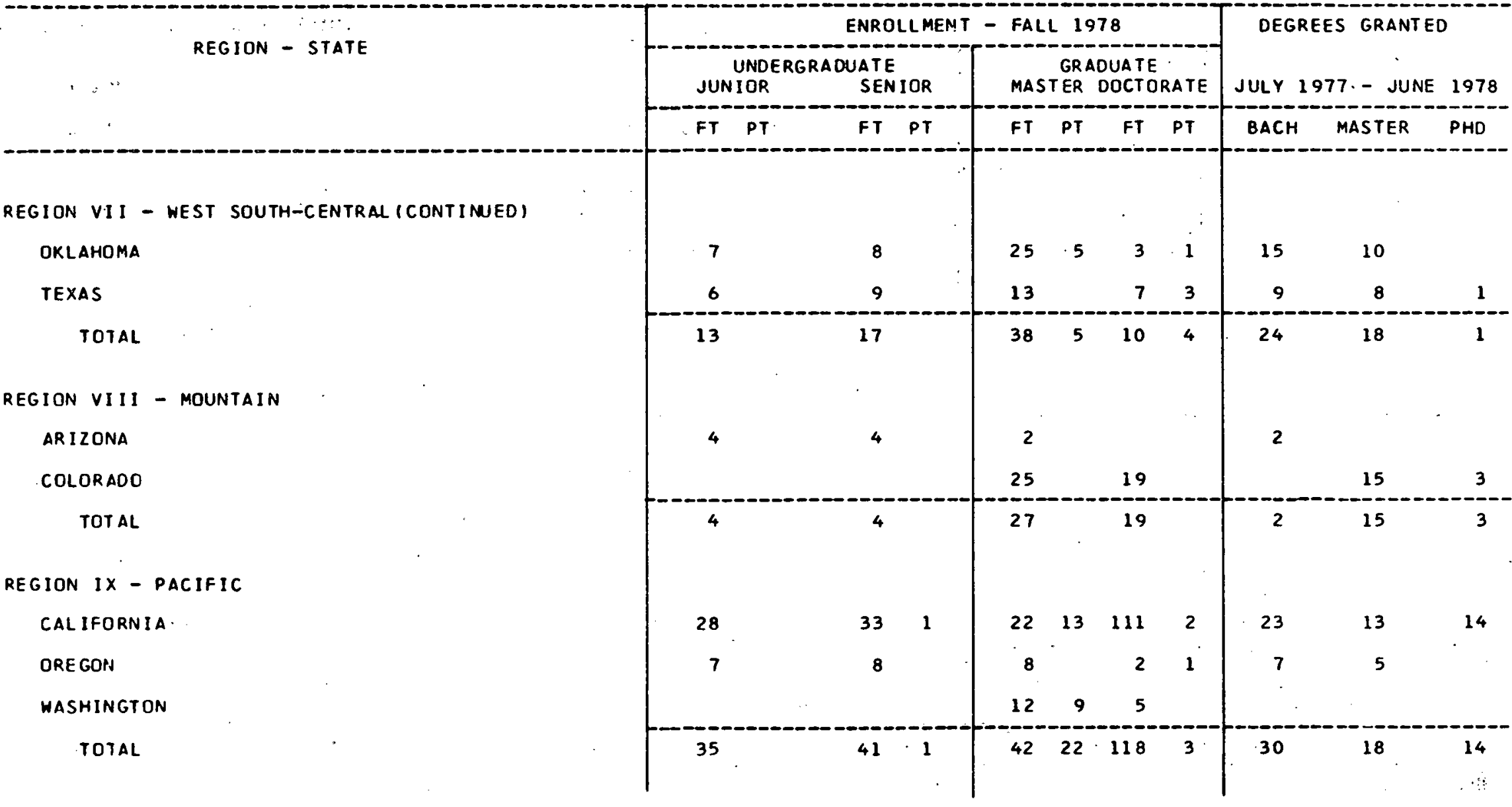


Arizona State University

Department of Engineering

Tempe, Arizona 85281

California State University, Los Angeles

Department of Physics

Los Angeles, California 90032

San Diego State University.

Department of Physics

San Diego, California 92182

University of California, Berkeley

Group in Biophysics and Medical Physics

Berkeley, California 94720

University of California, Los Angeles

Department of Radiological Sciences

Los Angeles, California 90024

Colorado State University

Department of Radiology and

Radiation Biology

Fort Collins, Colorado 80523

University of Colorado Medical Center

Department of Radiology

Denver, Colorado 80262

University of Florida

Department of Nuclear Engineering Sciences

and Department of Environmental Engineering

Gainesville, Florida 32611

Emory University

Department of Radiological Sciences

Decatur, Georgia 30322
Georgia Institute of Technology

School of Nuclear Engineering

Atlanta, Georgia 30332

Northwestern University

Department of Civil Engineering

Evanston, Illinois 60201

University of Chicago

Department of Radiology

Chicago, 111 inois 60637

University of Illinois, Urbana

Nuclear Engineering.Program

Urbana, Illinois 61801

Butler University

Department of Bionucleonics

Indianapolis, Indiana 46208

Purdue University

Department of. Bionucleonics

West Lafayette, Indiana 47907

University of Iowa

Radiation Research Laboratory

Iowa City, Iowa 52242

University of Kansas

Department of Radiation Biophysics

Lawrence, Kansas 66045

University of Kentucky

Department of Health Radiation Sciences

Lexington, Kentucky. " 40506 


\section{APPENDIX B-1 (Continued)}

ADDRESSES OF INSTITUTIONS IN SURVEY UNIVERSE WITH ACTIVE PROGRAMS

\section{RADIATION PROTECTION}

The Johns Hopkins University

School of Hygiene \& Public Health

Department of Environmental Health Sciences

Baltimore, Maryland 21205

Harvard University School of Public Health Department of Environmental Health Sciences Boston, Massachusetts. 02115

University of Lowell

Department of Radiological Sciences/Protection

Lowe17, Massachusetts 01854

University of Michigan

Department of Environmental

and Industrial Health
University of Minnesota

Department of Environmental Health

Minneapolis, Minnesota 55455

St. Louis University

Department of Physics

St. Louis, Missouri 63103

University of Missouri, Columbia Department of Nuclear Engineering Columbia, Missouri 65211.

Rutgers University

Department of Radiation Sciences

New Brunswick; New Jersey 08903

Clarkson Coillege of Technology

Department of Physics

Potsdam, New York 13676
Corne 11 University Graduate School of Medical Sciences

Memorial Sloan-Kettering Cancer Center

1275 York Avenue

New York, New York 10021

Manhattan College

Department of Radiological and Health Sciences

Riverdale, New York 10471

New York University Medical Center

Department of Environmental Medicine

New York, New York 10016

Rensselaer Polytechnic Institute

Department of Chemical \& Environmental

Engineering

Troy, New York 12181

University of Rochester

School of Medicine \& Dentistry

Department of Radiation Biology and Biophysics

Rochester; New York 14642

University of North Carolina, Chapel Hill Department of Environmenta] Sciences and Engineering

Chapel Hill, North Carolina 27514

Ohio State University

Department of Biophysics

Columbus, Ohio 43210

University of Cincinnati

Department of Radiology

Cincinnati, ohio 45267 
APPENDIX B-1 (Continued)

ADDRESSES OF INSTITUTIONS IN SURVEY UNIVERSE WITH ACTIVE-PROGRAMS

RADIATION PROTECTION

Oklahoma State University

Department of Radiation and

Nuclear Technology

Stillwater, Oklahoma 74074

University of Oklahoma

Health Sciences Center

Department of Environmental Health

Norman, Oklahoma 73190

Oregon State University

Department of General Science

Corvalitis, Oregon 97331

Oregon State University

Copartment of Nuclear Engineering

Corvallis, Oregon 97331

Duquesne University

Department of Radiological Health

Pittsburgh, Pennsylvania 15219

Temple University School of Pharmacy

Department of Pharmaceutical Chemistry

Philadelphia, Pennsylvania 19140

University of Pittsburgh, Graduate School of Public Health

Department of Radiation Health

Pittsburgh, Pennsylvania 15261

University of Tennessee, Chactanooga

Department of Physics

Chattanooga, Tennessee 37401

Vanderbilt University

Department of Physics-Astronomy

Nashville, Tennessee 37235
Texas A\&M University

Department of Radiological Safety

College Station, Texas 77843

University of Texas Health Science Center, Dallas

Department of Radiology

Dallas, Texas 75235

University of Texas Health Science Center, San Antonio

Department of Radiology

San Antonio, Texas 78284

University of Virginia Hospital

Radiology Department

Charlottesville, Virginia 22908

Virginia Polytechnic Institute and State University

Department of Biology

Blacksburg, Virginia $2406 \overline{1}$

University of Washington

Department of Radiological Sciences

Seattle, Washington 98195

University of Wisconsin, Madison

Department of Radiology-Medical Physics

Madison, Wisconsin 53706 


\section{APPENDIX B-2}

\section{ADDRESSES OF INSTITUTIONS IN SURVEY UNIVERSE}

WITH INACTIVE, AND DISCONTINUED PROGRAMS

RADIATION PROTECTION

\section{INACTIVE}

University of Alabama, Birmingham

Department of Physics

Birmingham, Alabama 35294

North Dakota State University

School of Pharmacy

Department of Pharmaceutical Chemistry

and Bionucleonics

Fargo, North Dakota 58105

University of Puerto Rico

Environmental Health Department

San Juan, Puerto Rico 00936

Middle Tennessee State University Department of Chemistry \& Physics Murfreesboro, Tennessee 37132

University of Tennessee, Knoxville Department of Physics

Knoxville, Tennessee 37916

\section{DISCONTINUED}

Carnegie-Mellon University St. Francis General Hospital Department of Radiation Oneology and Nuclear Medicine

Pittsburgh, Pennsylvania 15201 
Department of Energy

Washington; D.C. 20545

September 22, 1978

Dear Professor:

You were recently sent a copy of Radiation Protection Enroliments and Degrees, 1977 (DOE/IR-0013), which reported the results of the seventh survey of colleges offering degrees in this field so important to the safe utilization of nuclear power. We are enclosing the forms for recording current (1978) data covering the same subject items.

Because of growing public awareness regarding the development of nuclear energy, there is increased interest in reliable data on the supply of persons trained in the field of radiation protection, particularly among policymakers, planners, employers, educators, and students. Many of these have used the results of past surveys.

The survey is being conducted by the Manpower Research Program unit of Oak Ridge Associated Universities under the sponsorship of the Department of Energy (DOE).

In completing the forms, please include all persons in degree programs which prepare the students to participate in conducting, coordinating, directing, or planning a program for the evaluation and control of radiation hazards for an installation, community, or state agency. A duplicate set of forms for your records and a self-addressed, postagepaid envelope are included for your convenience. We would greatly appreciate receiving your completed questionnaire by October 30,1978 . Please enclose with the questionnaire the latest literature describing your program so that DOE staff can keep current on your program content.

If you have any questions about the questionnaire, please call collect to Dr. Larry Blair, Oak Ridge Associated Universities, (615) 483-8411, extension 371 . 


\section{APPENDIX C (Continued)}

We appreciate your continuing cooperation in this project and would be pleased to receive any comments you have on the survey content or form. Thank you again for your time and interest.

Sincerely,

Norman Seltzer

Deputy Director for Manpower Assessment Division of Labor Affairs and Manpower

Assessment 
APPENDIX C (Continued)

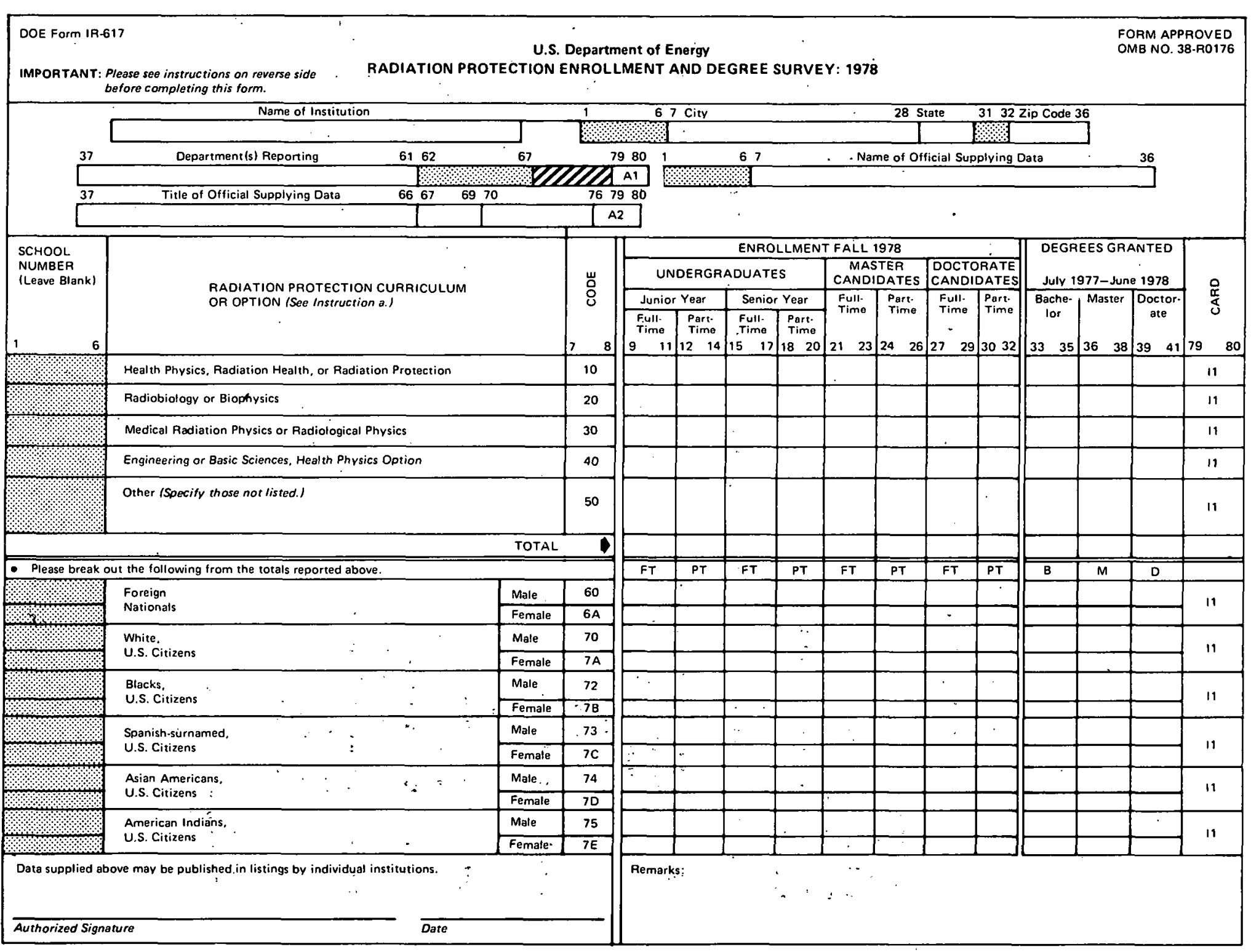




\title{
APPENDIX C (Continued)
}

\author{
U.S. Department of Energy \\ IR/EBLA/LAMA \\ Washington, D.C. 20545
}

Radiation Protection Enrollment and Degree Survey

\section{INSTRUCTIONS FOR COMPLETING DOE FORM IR-617}

This survey is conducted by the U.S. Department of Energy as part of its continuing effort to assure itself and its contractors a supply of well prepared experts in the nuclear field. With this questionnaire we hope to determine, by degree level, the yearly supply and anticipated supply of those trained in heal th physics, radiation health or safety, radiological health, or similar programs, who would be qualified to be responsible for some major phase of a program for the evaluation and control of radiation.hazards.

please Read the following instructions before filling out the Questionnaire:

Instr. a. Curriculum. Using a separate line for each major program, report only curricula which prepare students to participate in conducting, coordinating, directing, or planning a program for the evaluation and control of radiation hazards for an installation. community, or state agency.

Combine very small specialities with related major areas.

Instr. b. Report only students enrolled definitely as candidates for a degree. Report co-op students ${ }^{*}$ as being enrolled full-time. If exact figures are not available, please give best estimate and indicate by " $E$ " after the estimated number.

Instr.c. Pre-Doctoral Degree. Enrollments for professional degrees beyond the bachelor's are to be included with master's degree enrollments to simplify this report. Also see Instr. d.

Instr. d. Doctoral Programs. Report only enrollments specifically leading to a doctorate. If ul timate graduate degree is uncertain, report as master candidates.

Instr. e. Women, Minorities, Foreign Students. Requests for information about women and minorities are numerous. The number of foreign nationals is important to predicting manpower supplies. Therefore, please provide as accurate a breakout as possible. Blanks will be treated as zeros.

"For purposes of this survey, a co-op student is defined as one who alternates sessions of schooling with sessions of employment in a position related to his academic specialty. 


\section{RADIATION PROTECTION ENROLLMENT AND DEGREE SURVEY-SUPPLEMENT}

Reporting Institution

Please indicate placement or plans of degree recipients for July 1977-June 1978 reported on DOE Form IR-617.

Date NOTE: "Graduates Returning to previously held jobs" and "Foreign Nationals" should also be included in "Total Graduates."

\begin{tabular}{|c|c|c|c|c|c|c|c|c|c|}
\hline \multirow[b]{2}{*}{$\begin{array}{l}\text { PLACEMENT OR PLANS } \\
\text { AFTER GRADUATION }\end{array}$} & \multicolumn{3}{|c|}{ BACHELORS } & \multicolumn{3}{|c|}{ MASTERS } & \multicolumn{3}{|c|}{ DOCTORATES } \\
\hline & $\begin{array}{l}\text { Total } \\
\text { Graduates }\end{array}$ & $\begin{array}{l}\text { Graduates } \\
\text { Returning to } \\
\text { Previously } \\
\text { Held Jobs }\end{array}$ & $\begin{array}{l}\text { Foreign } \\
\text { Nationals }\end{array}$ & $\begin{array}{l}\text { Total } \\
\text { Graduates }\end{array}$ & $\begin{array}{l}\text { Graduates } \\
\text { Returning to } \\
\text { Previously } \\
\text { Held Jobs }\end{array}$ & $\begin{array}{l}\text { Foreign } \\
\text { Nationals }\end{array}$ & $\begin{array}{l}\text { Total } \\
\text { Graduates }\end{array}$ & $\begin{array}{l}\text { Graduates } \\
\text { Returning to } \\
\text { Previously } \\
\text { Held Jobs }\end{array}$ & $\begin{array}{l}\text { Foreign } \\
\text { Nationals }\end{array}$ \\
\hline \multicolumn{10}{|l|}{ Further study } \\
\hline \multicolumn{10}{|l|}{$\begin{array}{l}\text { U.S. Academic employment } \\
\text { (show students employed } \\
\text { part time under further } \\
\text { study) }\end{array}$} \\
\hline \multicolumn{10}{|l|}{$\begin{array}{l}\text { Federal Government } \\
\text { employment }\end{array}$} \\
\hline \multicolumn{10}{|c|}{$\begin{array}{l}\text { GOVERNMENT-owned, Con- } \\
\text { tractor-operated installa- } \\
\text { tions employment (GOCO's) }\end{array}$} \\
\hline \multicolumn{10}{|l|}{$\begin{array}{l}\text { State and Local } \\
\text { Government employment }\end{array}$} \\
\hline \multicolumn{10}{|l|}{$\begin{array}{l}\text { Medical Facilities } \\
\text { (Including Teaching } \\
\text { Hospitals) Employment }\end{array}$} \\
\hline \multicolumn{10}{|l|}{$\begin{array}{l}\text { Industrial employment } \\
\text { within U.S. }\end{array}$} \\
\hline \multicolumn{10}{|l|}{$\begin{array}{l}\text { Employment with foreign } \\
\text { employer }\end{array}$} \\
\hline \multicolumn{10}{|l|}{ U.S. Military service } \\
\hline \multicolumn{10}{|l|}{ Other (specify) } \\
\hline \multicolumn{10}{|l|}{ Still seeking employment } \\
\hline Unknown & & & & & & & & & \\
\hline
\end{tabular}

